UNIVERSIDADE DE BRASÍLIA

CÁTEDRA UNESCO DE BIOÉTICA

RAFAELA MENDES MEDEIROS

ENTRE AS POLÍTICAS SOCIAIS E A AUTONOMIA A PARTIR DOS CONCEITOS BIOÉTICOS: O EXEMPLO DA POLÍTICA DE HIV/AIDS

BRASÍLIA

2016 
RAFAELA MENDES MEDEIROS

\section{ENTRE AS POLÍTICAS SOCIAIS E A AUTONOMIA A PARTIR DOS CONCEITOS BIOÉTICOS: O EXEMPLO DA POLÍTICA DE HIV/AIDS}

Dissertação apresentada como requisito parcial à obtenção do título de mestre em Bioética, Programa de Pósgraduação na Cátedra da Unesco de Bioética da Universidade de Brasília.

Área de concentração: Bioética

Orientador: Prof. Dr. Miguel Ângelo Montagner 
MENDES MEDEIROS, Rafaela. Entre as políticas sociais e a autonomia a partir dos conceitos bioéticos: o exemplo da política de HIV/aids. Dissertação (Mestrado em Bioética). Programa de Pós-Graduação em Bioética. Brasília: Universidade de Brasília, 2016. Orientação: Miguel Ângelo Montagner. 


\section{Rafaela Mendes Medeiros}

\section{Entre as políticas sociais e a autonomia a partir dos conceitos bioéticos: o exemplo da}

política de HIV/aids

Dissertação apresentada à Cátedra da Unesco de Bioética da Universidade de Brasília para obtenção do título de mestre em Bioética

\section{Banca Examinadora}

Prof $^{\mathrm{o}}$. Dro . Miguel Ângelo Montagner (Presidente)

Universidade de Brasília

Prof $^{a}$ Dr $^{\mathrm{a}}$ Maria Inez Montagner (Membro)

Universidade de Brasília

$\operatorname{Prof}^{\mathrm{o}} \operatorname{Dr}^{\circ}$ Natan Monsores de Sá (Membro)

Universidade de Brasília

Prof $^{a}$ Dr $^{a}$ Flávia Reis de Andrade (Suplente)

Universidade de Brasília 
Dedico às pessoas que amo, principalmente ao meu companheiro, Daniel Lyra Rocha, e à nossa filha que ainda está em meu ventre, Eloah. 


\section{AGRADECIMENTOS}

Agradeço aos meus pais, Mary e Antônio, e minha irmã, Graziela, e seu companheiro, Nestor, que foram muito apoiadores nesse período.

Agradeço à família do meu marido, principalmente à Valéria, minha sogra, que me apoiou e conversou sobre o que é fazer um mestrado.

Agradeço ao meu orientador, Miguel Ângelo Montagner.

Agradeço ao Volnei Garrafa, pelo grande apoio ao final do mestrado.

Agradeço à banca da defesa, professores(as) Inez Montagner e Natan Monsores, e a professora suplente, Flávia Andrade.

Agradeço às colegas do trabalho, principalmente à Ana Roberta, minha chefe, que foi muito compreensiva sempre que precisei.

Agradeço à Gabi, Kauara, Rodrigo e Ana, que de colegas de carreira e/ou trabalho, tornaram-se queridos/as amigos/as e me apoiaram muito na jornada do mestrado.

Agradeço ao meu amor e companheiro, Daniel Rocha, e à nossa filha que está por vir, a amada Eloah. 


\section{A ideia}

Augusto dos Anjos

De onde ela vem?! De que matéria bruta Vem essa luz que sobre as nebulosas

Cai de incógnitas criptas misteriosas

Como as estalactites duma gruta?!

Vem da psicogenética e alta luta

Do feixe de moléculas nervosas,

Que, em desintegrações maravilhosas,

Delibera, e depois, quer e executa!

Vem do encéfalo absconso que a constringe,

Chega em seguida às cordas da laringe,

Tísica, tênue, mínima, raquítica ...

Quebra a força centrípeta que a amarra, Mas, de repente, e quase morta, esbarra No mulambo da língua paralítica. 


\section{RESUMO}

O presente trabalho tem como objetivo entender melhor, à luz do conceito de autonomia e justiça da bioética, como as visões desses mesmos conceitos são vistos pelos formuladores e gestores de políticas sociais de saúde referentes ao HIV/Aids no país. Foi feito um estudo sobre o conceito de política social no Brasil e o conceito de justiça que o baseia, sempre pensando em alargar o conceito à luz da visão bioética. Além disso, foi investigado como o conceito de autonomia em práticas consideradas de risco à transmissão do HIV e do fato de algumas pessoas não quererem se tratar quando HIV positivos são vistos por formuladores e gestores de políticas sociais de saúde relacionadas ao HIV, também à luz dos conceitos bioéticos. Para isso, foram entrevistadas 6 (seis) pessoas que trabalham na gestão do Ministério da Saúde e que lidam diretamente com os temas de políticas sociais de HIV. As falas delas serviram para exemplificar os conceitos de justiça, autonomia e equidade que embasam as políticas sociais, sempre pensando em suas realidades diárias de trabalho.

Palavras-chave: política social; HIV; autonomia; justiça; bioética. 


\begin{abstract}
This study aims to understand, in the light of the concepts of autonomy and justice of bioethics, how formulators and social health policy makers related to HIV/aids in the country understand those same concepts. The concept of social policy in Brazil and the concept of justice that bases those policies were studied aiming on extending these concepts in the light of bioethics. Furthermore, it was investigated how the concept of autonomy in risky practices to HIV transmission and the fact some HIV positive people do not want to go on treatment are seen by formulators and social policy makers of health related to HIV, also in the light of the bioethical concepts. Six (6) people who deal directly with the issues of social HIV policies were interviewed at their working places at the Ministry of Health. Their statements were used in this research to illustrate the concepts of justice, autonomy and equity that support social policies, always concentrating on their daily realities of work.
\end{abstract}

Keywords: social policy; HIV; autonomy; justice; bioethics. 


\section{LISTA DE FIGURAS}

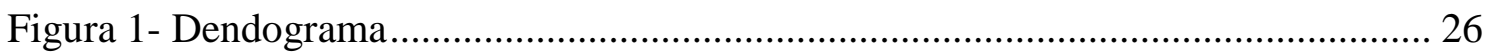

Figura 2- Organização dos temas da dissertação........................................................... 26

Figura 3 - Organização das políticas transversais no Brasil atual. ............................... 40

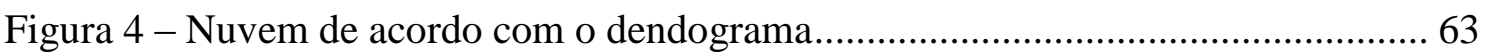




\section{LISTA DE QUADROS}

Tabela 1 - Modelos de Proteção Social........................................................................... 31

Tabela 2 - Dinâmica das políticas sociais no Brasil (1988-2009). ................................ 34 


\section{LISTA DE ABREVIATURAS E SIGLAS}

CF/88 - Constituição Federal de 1988

CNS - Conselho Nacional de Saúde

DAGEP - Departamento de apoio à Gestão Participativa

DDAHV - Departamento de HIV/aids, DST e Hepatites Virais

DST - Doenças sexualmente transmissíveis

HIV - Vírus da imunodeficiência humana

IPEA - Instituto de Pesquisa Econômica Aplicada

IRAMUTEQ - Interface de $\mathrm{R}$ pour les Analyses Multidimensionnelles de Textes et de Questionnaires

LGBT - Lésbicas, Gays, Bissexuais e Trans/Travestis

MS - Ministério da Saúde

MST - Movimento dos sem-terra

OAB - Ordem dos Advogados do Brasil

ONG - Organização não-governamental

PCDT - Protocolo clínico de diretrizes terapêuticas

PDRAE - Plano Diretor de Reforma do Aparelho do Estado

PPA - Plano Plurianual

SGEP - Secretaria de Gestão Participativa

SUS- Sistema Único de Saúde

TARV - Tratamento antirretroviral 


\section{SUMÁRIO}

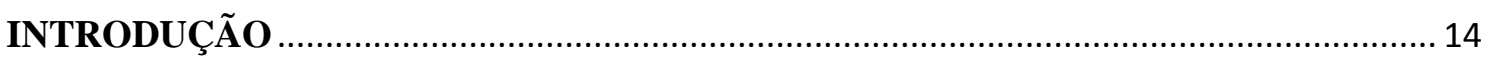

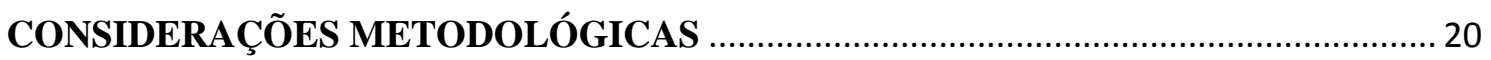

CAPítUlO I. DA POLÍTICA SOCIAL À PARTICIPAÇÃo SOCIAL NO CONTEXTO DA POLÍTICA

Expansão da bioética para as questões sociais 27

Conceitos fundamentais para se pensar as políticas sociais relacionadas à saúde no contexto ocidental.. 30

O que vem a ser essa política social? 32

A participação da população nas políticas sociais de saúde no contexto brasileiro. 35

O conceito de justiça nas políticas sociais 38

CAPÍTULO 2. AUTONOMIA INDIVIDUAL E COLETIVA 46

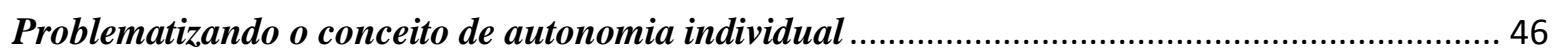

Alargando o conceito de justiça social e pensando a autonomia coletiva ...................................... 50

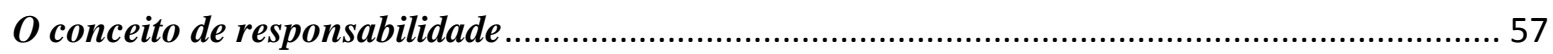

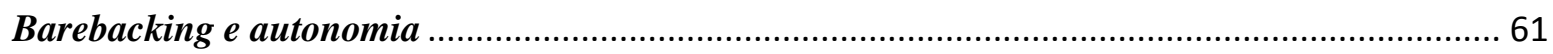

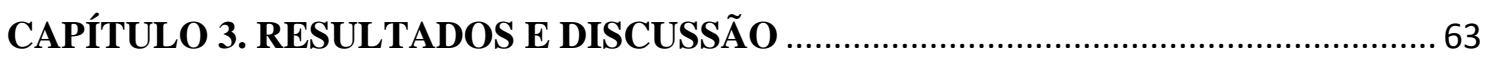

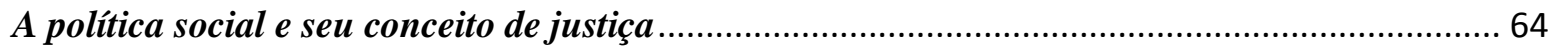

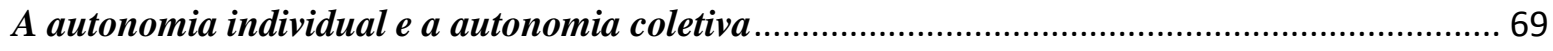

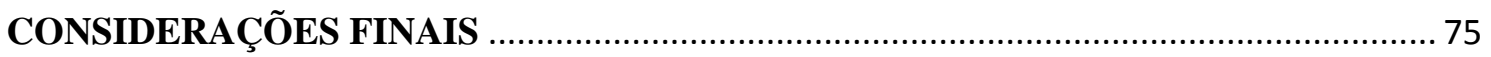

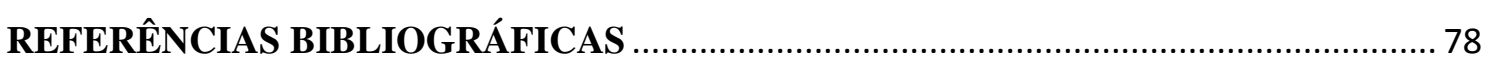

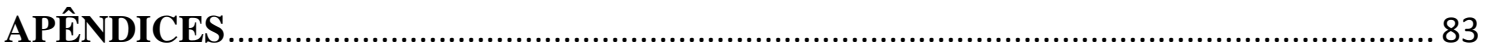

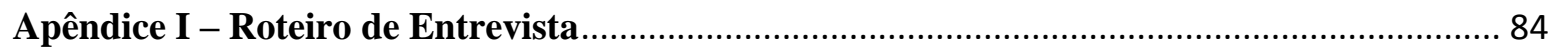

Apêndice II - Termo de Consentimento Livre e Esclarecido (TCLE) ……............................... 85 


\section{INTRODUÇÃO}

\section{Implicações}

Inicialmente, a escolha do tema foi intensamente baseada na minha prática diária de trabalho. Trabalho como analista de políticas sociais no Ministério da Saúde e entrei no serviço público sem saber em que área iriam me alocar após passar no concurso. Após a entrevista na Secretaria de Vigilância em Saúde, por já ter tido experiência com movimentos sociais na área da cultura, fui alocada na área de direitos humanos e prevenção ao HIV no Departamento de HIV/aids, DST e Hepatites Virais.

Anteriormente, quando trabalhando na cultura (Instituto Brasileiro de Museus), com o tema de educação e museologia social, percebi que o tema da relação entre Estado e Sociedade Civil despertou fortemente meu espírito inquisidor e pesquisador. As perguntas que me vinham giravam em torno da causa dos movimentos sociais, que naquele momento histórico (2010 a 2013), "enfrentavam" o Estado, mas ao mesmo tempo necessitavam dele, quer por meio de orçamento quer por meio de cargos públicos. Esta era a minha vivência diária.

Ao ir para o campo da saúde, a vivência em relação aos movimentos sociais e à saúde, mais especificamente a aids, fez com que eu quisesse entender essa relação que já me intrigava quando eu estava na cultura. O movimento social ligado ao tema de HIV/aids é de extrema importância para o Brasil e para o mundo em relação à formação do próprio programa no âmbito do Ministério da Saúde. O próprio contexto dos anos 1970 e 1980 está ligado às conquistas de liberdades individuais e ao início do reconhecimento dos direitos de mulheres, homossexuais e negros, por exemplo. Segundo Grangeiro, Silva e Teixeira (1), este panorama de ativismo político levou à uma reação dos movimentos sociais frente à aids, "tanto no plano de atenção à saúde como na prevenção e no combate às situações de discriminação dirigidas aos grupos mais afetados e às pessoas vivendo com HIV/aids".

O movimento da reforma sanitária, com seu início datado nos anos 1980, fundamentou os princípios e diretrizes da política de aids desenvolvida no âmbito governamental. O ativismo político efervescente dos anos 1970 e 1980 permitiu a imediata reação de movimentos sociais frente à aids, tanto no plano da atenção à saúde como na prevenção e no combate às situações de discriminação dirigidas aos grupos mais afetados e às pessoas vivendo com HIV e aids. Em 1983 tem-se a primeira resposta governamental à epidemia, com 
a criação do Programa de Aids da Secretaria de Estado da Saúde no Estado de São Paulo, que foi uma resposta às inquietações de representantes da comunidade homossexual. Este programa articulou-se em torno de quatro estratégias: serviços de referência assistencial e laboratorial, vigilância epidemiológica, informação e educação à população e mobilização e participação social. Entre as suas diretrizes, temos o combate à discriminação, a garantia do acesso universal ao tratamento e a promoção da equidade para os grupos sociais mais afetados no acesso aos recursos disponíveis. O papel que a sociedade civil desempenhou na construção da resposta à epidemia de aids é de extrema importância, tanto pela ação em comunidade, com a finalidade de reduzir a prevalência e a mortalidade por aids, quanto pela busca caracterização das políticas de saúde por meio da militância e do controle social (1).

Dessa forma, o registro dos primeiros casos de aids no país, em 1983, teve, também, um impacto no movimento homossexual, intensificando o seu enfraquecimento enquanto movimento pelas causas estritamente homossexuais e levando uma parte dos ativistas a se articular em torno da luta contra a aids, constituindo-se em um dos principais pilares da resposta à epidemia de aids no país. Nos anos que se seguiram aos primeiros casos de aids no país e de mudança em relação ao próprio movimento pelas causas homossexuais, tornou-se difícil distinguir a militância do movimento homossexual da militância do movimento de luta contra a aids, o que permitiu, como desdobramento, os avanços em relação ao fortalecimento do movimento das profissionais do sexo e de usuários de drogas (1).

\section{A questão social desta pesquisa}

A política social de saúde de HIV/aids no Brasil, quando pensada em termos sanitários, baseia-se, desde 2013, no Protocolo Clínico e Diretrizes Terapêuticas para Manejo da Infecção pelo HIV em Adultos (PCDT) que recomenda estimular o início imediato da terapia antirretroviral - TARV - para todas as pessoas vivendo com HIV/Aids, na perspectiva de redução da transmissibilidade do HIV. O protocolo diz que em nenhuma situação deverá haver qualquer tipo de coerção para início da terapia antirretroviral (TARV), mas é necessário enfatizar o alto nível de evidência de que a supressão viral pode reduzir significativamente a transmissão sexual do HIV. O tratamento poderá ser iniciado desde que a pessoa que vive com HIV seja esclarecida sobre benefícios e riscos, além de fortemente motivada e preparada para o tratamento, respeitando-se a autonomia do indivíduo. Antes desse protocolo, o início 
do tratamento acontecia com contagem de linfócitos CD4 acima de 500 células/mm3, sendo que agora pode-se iniciar o tratamento independentemente do CD4 (2).

Além desses aspectos, sabe-se que, de acordo com o boletim epidemiológico de aids e DST de 2013 do Departamento de HIV/aids, Hepatites Virais e Infecções Sexualmente Transmissíveis (DDAHV), com relação aos grupos populacionais com mais de 18 anos em contexto de maior vulnerabilidade social, estudos realizados em 10 municípios brasileiros entre 2008 e 2009 estimaram taxas de prevalência de HIV de 5,9\% entre usuários de drogas, de $10,5 \%$ entre homens que fazem sexo com homens e de 4,9\% entre mulheres profissionais do sexo (3).

\section{Questão Bioética}

Ao ser colocada a questão da universalidade do tratamento para pessoas que vivem com HIV, é importante pensar o conceito de autonomia de se tratar ou não quando a pessoa se descobre portadora do vírus HIV. Este conceito fundamentou a bioética clássica, que epistemologicamente baseia-se no saber médico e clínico e restringiu-se a temas, problemas e conflitos primordialmente individuais em detrimento aos coletivos. (4) O princípio de respeito à autonomia ${ }^{5}$ tem suas raízes na tradição liberal ocidental que valoriza a liberdade individual, tanto para a vida política quanto para o desenvolvimento pessoal. Para Beauchamp (5), "autonomia" e "respeito à autonomia" são termos geralmente ligados às ideias de privacidade, escolha livre e aceitação da responsabilidade na escolha feita pelo o indivíduo, principalmente na relação médico-paciente.

Seguindo o pensamento bioético ampliado, Garrafa (6) propõe a necessidade de ampliação da agenda bioética para além das questões biomédicas, por meio da utilização de novos referencias teóricos e metodológicos. Dessa forma, a autonomia também deve ser vista para além de seu conceito clássico individualista, como um espaço de liberdade e de independência, de uma forma em que a subjetividade se concretiza diante do outro, por meio da abertura para o diálogo e da interação com o outro. O sujeito que pretende afirmar-se enquanto autônomo abdica de sua singularidade ao pensar-se como parte da humanidade (conjunto de sujeitos que possuem, tanto quanto ele, singularidades e subjetividades próprias). Esse conceito está mais ligado à coletividade do que à autonomia individualista, pois é a partir da alteridade que suas decisões são tomadas (7). 
O que temos que deixar claro é que essa noção de autonomia ampliada se contradiz ou se contrapõe, em certa medida, com um conceito muito caro no âmbito das políticas sociais: a justiça ou igualdade de tratamento para todos que, no caso, seria a política nacional do HIV. De acordo com Fortes e Zoboli (8), a saúde pública é o que a sociedade faz coletivamente para assegurar condições para que as pessoas sejam saudáveis, inserindo-se como campo de saber científico e de práticas normalmente efetivadas pelos órgãos estatais. O problema é que essas ações podem gerar conflitos morais, pois podem vir a limitar ou restringir liberdades e decisões individuais e, além de tudo, baseiam-se na noção ética utilitarista do maior benefício para a maior quantidade de pessoas, controlando estilos e comportamentos de vida que são considerados não-saudáveis, preconizando o que seria uma vida perfeita.

Fortes (9), ao refletir sobre o princípio ético da justiça distributiva aplicado aos sistemas de saúde, afirma que a efetivação desse princípio evidencia o pluralismo de valores morais e a diversidade de interpretações do que seria a justa distribuição de recursos na esfera pública. Caso a escolha da justiça a ser aplicada seja marcada pelo princípio da diferença, isto é, de que deva tratar-se diferenciadamente as pessoas de acordo com suas necessidades individuais, a máxima orientadora dessa aplicação seria o da equidade - tratamento igual para os iguais e desigual para os desiguais.

No caso da presente dissertação, a questão que se coloca é a de, a partir de um ponto de vista da política social, deve-se ofertar tratamento para todas as pessoas que descobrem que estão com o HIV e, ao mesmo tempo, cercear a possibilidade de essa pessoa, dentro de sua autonomia de escolha, não querer se tratar?; e, indo mais além, as pessoas podem ser consideradas autônomas para tomarem decisões de ter comportamentos de risco? Tomamos como exemplo o caso de homens gays que fazem sexo sem preservativo, muitas vezes não sabendo a condição sorológica do parceiro sexual. Seria fácil pensar que tomando atitudes de risco, a possibilidade de que essa pessoa passe o vírus para outra é muito maior por conta da carga viral.

Dessa forma, o que temos, é o antagonismo entre a política social de tratamento para todos e a possibilidade de escolha de não tratamento e de ter atitudes de risco de contaminação do HIV, no caso de fazer sexo sem preservativo.

Podemos ir além e pensar sobre a prática, entre algumas pessoas da população gay, do que é chamado barebacking. Segundo Girard (10), este é um termo com vários significados, mas que geralmente refere-se à prática sexual sem preservativo, também podendo significar 
identidades ou pertencimento a determinados espaços. Partindo do risco como fator usado para designar responsabilidades coletivas e/ou individuais, o autor se propôs a entender as relações dimensionais e relacionais do ato deliberado de fazer sexo sem preservativo a partir de um entendimento sociológico.

\section{Objetivos}

O objetivo geral dessa dissertação é entender, à luz do conceito de autonomia e justiça da bioética, como as visões de justiça e autonomia são vistas formuladores e militantes de políticas sociais de saúde relacionadas ao HIV que trabalham no Ministério da Saúde.

Como objetivos específicos, foram definidos:

1. Investigar como o conceito de justiça, equidade e universalidade são vistos por formuladores e militantes de políticas sociais de saúde relacionadas ao HIV que trabalham no Ministério da Saúde, à luz dos conceitos bioéticos;

2. Investigar como o conceito de autonomia em práticas consideradas de risco à transmissão do HIV e do fato de não quererem se tratar quando HIV positivos são vistos formuladores e militantes de políticas sociais de saúde relacionadas ao HIV que trabalham no Ministério da Saúde, à luz dos conceitos bioéticos.

\section{Forma de apresentação desta dissertação}

A dissertação inicia-se fazendo uma introdução teórica baseando-se na bioética de intervenção e sua possibilidade de alargamento dos conceitos de justiça e autonomia. No decorrer do trabalho (capítulos 1 e 2), tento tecer a fala dos entrevistados e os conceitos utilizados na pesquisa para que um exemplifique o outro e sirva para melhor entendimento da realidade vivida na política social hoje em dia ou mesmo para se pensar a possibilidade de ir além do que atualmente é uma política social e do que é visto como autonomia.

O capítulo 1 versa sobre a política social, considerando o conceito de justiça relacionado à seguridade social no seu contexto do Estado de bem-estar social. Desse enfoque social, eu parti para se pensar a participação social, que ficará mais claro na dissertação quando estiver caracterizada a participação das pessoas da militância na gestão e na formulação de políticas públicas. 
No capítulo 2, já afunilando do conceito inicial maior de política social, trabalho com o conceito de autonomia individual e coletiva, além do conceito de justiça em seu sentido mais amplo de esbarrar na conceituação de alteridade. No capítulo 3, de discussão dos resultados, trabalho a fala dos entrevistados revisitando os conceitos estudados e escritos nos capítulos 1 e 2 e baseando-me nos achados gerados pelo IRAMUTEQ. 


\section{CONSIDERAÇÕES METODOLÓGICAS}

\section{Consentimento para a pesquisa}

Vale ressaltar que, de acordo com a Resolução CNS 466/12, os princípios da autonomia, beneficência, justiça e não-maleficência devem ser respeitados ao serem realizadas pesquisas em que estejam sendo envolvidos seres humanos. Os pontos importantes da resolução referem-se a prevenir malefícios e garantir que os participantes tenham acesso aos benefícios provenientes de sua inserção em uma investigação; os indivíduos devem ser totalmente capazes, sendo que muitos grupos são considerados vulneráveis, como incapazes, indígenas, etc.; os sujeitos têm direito de serem informadas sobre a natureza da pesquisa, de recusar-se a participar de uma pesquisa, de preservação de sua intimidade, de acordo com seus padrões culturais, de ter acesso aos resultados da investigação, de autoria e coautoria das populações sobre sua própria produção cultural e de ter seus códigos culturais respeitados através de várias formas sobre o significado de termos de consentimento, além de ter a garantia de que a colaboração prestada à investigação não seja utilizada com o intuito de prejudicar o grupo investigado. Levando-se em consideração os termos acima, o trabalho propõe-se a respeitar todos os processos éticos referentes à resolução 466/12. (12)

Para minimização de risco, a pesquisadora comprometeu-se com a devolução dos resultados da pesquisa e com o fato de que os entrevistados e entrevistadas receberiam uma adequada e acurada descrição e informação dos riscos, desconfortos e dos benefícios que podem ocorrer, além da proteção à confidencialidade e privacidade dos voluntários. Além disso, foi frisado que há benefício ao se fazer essa pesquisa, pois é uma forma de se entender melhor a política de HIV/Aids no país e a forma como as pessoas veem conceitos importantes para a política social de saúde do HIV, como os conceitos de equidade, universalidade, justiça e autonomia.

\section{Tipo de estudo}

Para alcance dos objetivos do projeto, a metodologia qualitativa foi adotada. Os dados foram coletados em Brasília - DF, por meio de diferentes fontes. Inicialmente, foi aprofundada a revisão da bibliografia sobre conceito de justiça nas políticas sociais, autonomia e universalidade, orientando a seleção dos textos com base na bioética. Para 
trabalhar como os conceitos a que nos propusemos, foram realizadas entrevistas semiestruturadas com pessoas, entre 22 e 65 anos, diretamente vinculadas ao tema de políticas sociais dentro do próprio Poder Executivo, no caso o Ministério da Saúde, mais especificamente, o Departamento de HIV/aids, Hepatites Virais e Infecções Sexualmente Transmissíveis (DDAHV).

As entrevistas com as pessoas do Ministério da Saúde seguiriam perguntas baseadas nos conceitos de justiça, universalidade e autonomia, em que as pessoas diziam sobre o cargo que ocupavam; a escolha de trabalhar com o tema de política social do HIV; o que elas entendiam como política social, justiça, equidade e universalidade; a possibilidade de autonomia de uma pessoa de não se tratar no caso de saber que é HIV positivo; e outras questões que surgiram ao longo da entrevista. A adoção de entrevistas semiestruturadas, de acordo com Boni e Quaresma (14), mostrou-se uma técnica adequada, especialmente devido à elasticidade na duração das entrevistas, permitindo aprofundamento em determinados assuntos, além da interação com as entrevistadas favorecer a enunciação de respostas espontâneas e o desdobramento em perguntas também espontâneas.

A abordagem dos participantes foi realizada da seguinte maneira: as 6 (seis) pessoas que estão diretamente vinculadas ao tema de políticas sociais dentro do próprio Poder Executivo foram entrevistadas em salas de reuniões do próprio Ministério da Saúde, ou no horário do almoço ou no fím do horário de expediente, conforme eles acharam melhor. A abordagem foi feita por meio de convite no próprio ambiente de trabalho. A escolha das pessoas foi feita de acordo com o fato de participarem diretamente no trabalho com as populações consideradas de maior vulnerabilidade ao HIV: 3 participam diretamente do grupo jovem e são jovens que fazem parte da militância do HIV nos grupos de pessoas transexuais e gays; e 3 são ou foram coordenadores nos últimos 10 anos da área que pensa a política diretamente para essas mesmas populações em contexto de maior vulnerabilidade ao HIV.

Como já dito acima, em relação aos grupos populacionais em situação de maior vulnerabilidade, as taxas de prevalência de HIV encontradas em estudos realizados pelo Departamento de DST, Aids e Hepatites Virais em 2008/2009 foram de 5,9\% entre usuários de drogas, $10,5 \%$ entre gays e homens que fazem sexo com homens e 4,9\% entre mulheres profissionais do sexo. Ainda não há dados que corroboram a alta taxa de prevalência entre travestis e transexuais no Brasil, mas de acordo com pesquisas em diversos países e pelo fato de elas fazerem parte dos dados de $\mathrm{HSH}$, esta é uma população de alto risco.(13) Para inclusão nas entrevistas das pessoas que trabalham na gestão no Ministério da Saúde, foi considerado critério de inclusão para as entrevistas pessoas que fazem parte da elaboração das 
políticas, isto é, quem trabalha ou trabalhou com o tema de prevenção ao HIV e, também, o grupo de jovens gays e transexuais que, no atual momento, estão pensando a abordagem aos jovens gays, travestis e transexuais, no país, em relação ao tema da prevenção ao HIV, já que essas são as populações que estão mais vulneráveis ao HIV no momento atual da epidemia.

Ao se analisar a importância da entrevista como técnica de coleta de dados para captação de dados subjetivos, ressaltam-se as vantagens na técnica de entrevista semiestruturada. A elasticidade na duração das entrevistas permite cobertura mais profunda sobre determinados assuntos, além de haver maior interação entre a entrevistadora e entrevistados, favorecendo respostas espontâneas. (14). Para orientar as entrevistas, foi utilizado roteiro de entrevista (Apêndice I).

Qualquer referência aos participantes, nessa pesquisa, foi por meio de pseudônimos. Cada uma das entrevistas foi realizada de forma individual, sem a interferência de terceiros/as, com estrita preocupação quanto ao sigilo das informações prestadas. Os entrevistados e participantes não foram abordados na rua e as entrevistas foram realizados conforme as pessoas acharam mais agradável de falarem.

Todas as entrevistas foram iniciadas com a leitura do Termo de Consentimento Livre e Esclarecido (Apêndice II) pelos entrevistados, na presença da pesquisadora. Foi reiterado que eu estava à disposição para quaisquer esclarecimentos necessários antes, durante e após a entrevista e de que caso eles quisessem desistir durante o processo, poderiam assim fazê-lo.

\section{Perfil e caracterização dos entrevistados}

Todas as pessoas entrevistadas têm um cargo dentro do governo e seguem os perfis abaixo (vale lembrar que os nomes foram modificados para melhor preservá-los):

Aílton tem 32 anos e trabalha a questão de prevenção e diagnóstico para o HIV da população-chave (gays, travestis, transexuais e profissionais do sexo), focando na população jovem. Descobriu que era soropositivo aos 25 anos e veio da militância do HIV, mais precisamente da Rede de Jovens Soropositivos. 
Anderson tem 54 anos e trabalha como coordenador da área de prevenção e articulação social. Entrou na política de DST/aids inicialmente quando se descobriu portador do vírus HIV, época em que trabalhou em uma organização não governamental (ONG) em São Paulo por 10 anos, período de militância no tema. Posteriormente trabalhou no Programa de DST/aids do município de São Paulo, onde trabalhou 4 anos e 6 meses, até ser chamado para trabalhar no governo federal.

Elana tem 22 anos e trabalha com a prevenção e diagnóstico para o HIV da população-chave (gays, travestis, transexuais e profissionais do sexo), focando na população jovem. Veio da militância estudantil e depois, por ser transexual, entrou na militância trans, o que a levou a trabalhar com o assunto de HIV/aids.

Aldo tem 24 anos e trabalha com a prevenção e diagnóstico para o HIV da populaçãochave (gays, travestis, transexuais e profissionais do sexo), focando na população jovem. Veio da militância estudantil e do movimento LGBT, trabalhando posteriormente com o tema de HIV/aids na ONU, até chegar no governo federal.

Haroldo tem 61 anos e há 20 anos trabalha no âmbito do governo federal no tema de HIV/aids. Coordenou a área de prevenção e articulação social por 5 anos e agora coordena a área relacionada a assuntos estratégicos e planejamento.

Iara tem 65 anos e há 20 anos trabalha no âmbito do governo federal no tema de HIV/aids. Sempre trabalhou com o tema de planejamento na gestão federal.

O conteúdo de todo o material obtido ao final da investigação foi sistematizado em subtemas referentes ao conceito de justiça e universalidade das políticas sociais e autonomia, baseados em um enfoque bioético, analisados por meio das falas ao longo da dissertação, exemplificando os eixos identificados de acordo com o software IRAMUTEQ, que será apresentado abaixo.

$\mathrm{Na}$ apresentação dos relatos, foram mantidas no texto as palavras, termos e expressões utilizados pelas informantes, interferindo o mínimo possível na representação de suas falas e elaborações. Reconhecendo e ressalvando os limites do meu lugar de pesquisadora, busquei valorizar e visibilizar suas experiências, bem como suas interpretações teóricas sobre a 
realidade. Entendo que os relatos, a partir do ponto de vista das informantes, configuram um ângulo privilegiado de conhecimento sobre a temática.

\section{A Análise Textual com Auxílio de Programas Informáticos: IRAMUTEQ}

Foram degravadas seis entrevistas utilizando-se o software livre denominado IRAMUTEQ (Interface de $\mathrm{R}$ pour les Analyses Multidimensionnelles de Textes et de Questionnaires) como forma de organização e análise dos dados. O IRAMUTEQ é um software gratuito e com fonte aberta, desenvolvido por Pierre Ratinaud (Lahlou, 2012; Ratinaud \& Marchand, 2012) e licenciado por GNU GPL (v2), que permite fazer análises estatísticas sobre corpus textuais e sobre tabelas indivíduos/palavras. Ele ancora-se no software R (www.r-project.org) e na linguagem Python (www.python.org).

Como o material produzido nas entrevistas, foi criado um material textual, chamado de corpus de análise. Com o IRAMUTEQ, foi feita a análise textual, que consiste num tipo específico de análise de dados, que se trata especificamente da análise de material verbal transcrito, produzido nas entrevistas. Por tratar-se de dados que são compostos essencialmente pela linguagem, os mesmos mostram-se relevantes aos estudos sobre pensamentos, crenças, opiniões - conteúdo simbólico produzido em relação a determinado fenômeno. (15)

Para esta pesquisa, foi utilizado o método da Classificação Hierárquica Descendente (CHD) proposto por Reinert (1990) e utilizado pelo software ALCESTE, que se encontra entre uma das análises possíveis com o IRAMUTEQ. O CHD classifica os segmentos de texto em função dos seus respectivos vocabulários, e o conjunto deles é repartido com base na frequência das formas reduzidas (palavras já lematizadas, isto é, palavras que serviram de entrada). Esta análise visa obter classes de Unidades de Contextos Elementares (UCE) que, ao mesmo tempo, apresentam vocabulário semelhante entre si e vocabulário diferente das UCE das outras classes (15).

O IRAMUTEQ também fornece outra forma de apresentação dos resultados, por meio de uma análise fatorial de correspondência feita a partir da CHD (Análise Pós-Fatorial) que representa num plano cartesiano as diferentes palavras e variáveis associadas a cada uma das classes da CHD. A interface possibilita que se recuperem, no corpus original, os segmentos 
de texto associados a cada classe, momento em que se obtém o contexto das palavras estatisticamente significativas, possibilitando uma análise mais qualitativa dos dados. (15)

\section{Utilização do software IRAMUTEQ na presente pesquisa}

Conforme descrito acima, e para organizar os dados, foi utilizado o método da Classificação Hierárquica Descendente (CHD) que se encontra no software IRAMUTEQ como uma das formas de análise de texto. (15) Inicialmente, foram processadas as 6 entrevistas, o que foi possível ter uma visão global e mais ampla das falas dos entrevistados. Ao rodar os dados, o software produziu a formação de um dendograma com dois eixos, um eixo que posicionou a classe 4 de um lado e as classes 1, 2 e 3 de outro lado. Em relação a estas últimas classes, houve uma nova divisão do eixo em 2 eixos, sendo que de um lado encontrou-se as classes 1 e 3 e dou outro a classe 2 . Vale lembrar que quanto mais perto as classes estão agrupadas nos eixos, maiores as relações entre elas.

Dessa forma, foram formados 3 (três) eixos, que englobaram as classes conforme está descrito no parágrafo acima. Com essa divisão montada pelo software, nomeei o primeiro eixo maior como "Política Social e Autonomia", pois ele abarca todas as 4 classes. O segundo eixo, que estaria dentro desse eixo maior que chamo de "guarda-chuva", abarca as classes 1, 2 e 3, e eu o nomeei de "Participação social no contexto da política". Seguindo essa mesma lógica vem o terceiro eixo que abarca as classes 1 e 3, que chamei de "Autonomia individual e coletiva" e organiza em suas classes palavras referentes ao tema de autonomia - tanto individual quanto coletiva - que apareceram nas falas dos entrevistados. As palavras que estão com um círculo em cada uma das classes são consideradas significativas em relação à associação da palavra com a classe na qual está inserida. 


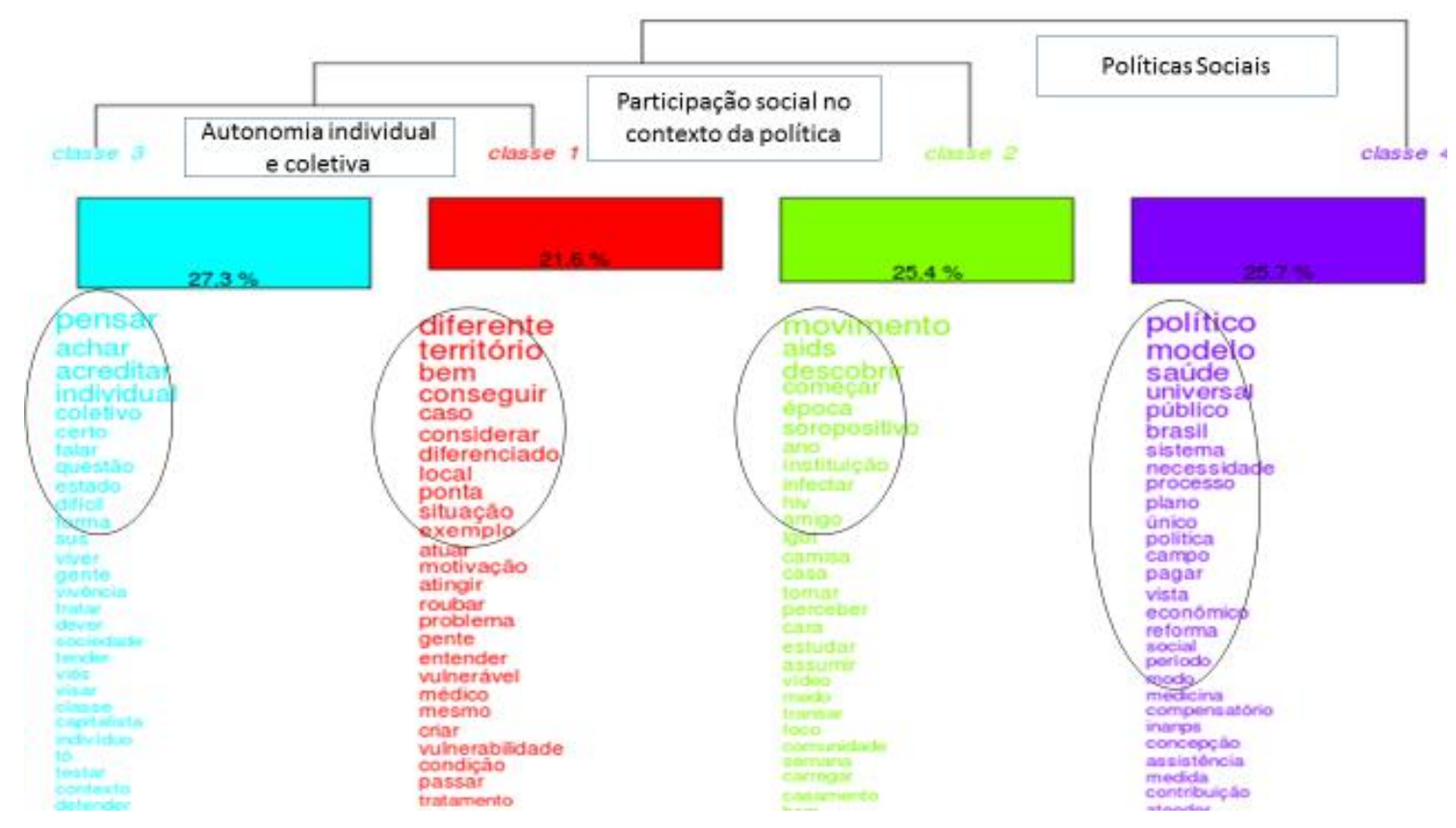

Figura 1- Dendograma gerado pelo software IRAMUTEQ ao rodar as entrevistas.

Para a presente pesquisa, o uso do IRAMUTEQ serviu como organizador da estruturação a pesquisa. Ao surgir os três eixos, a montagem da dissertação foi organizada tendo como base a ideia de um eixo contendo o outro, conforme figura abaixo:

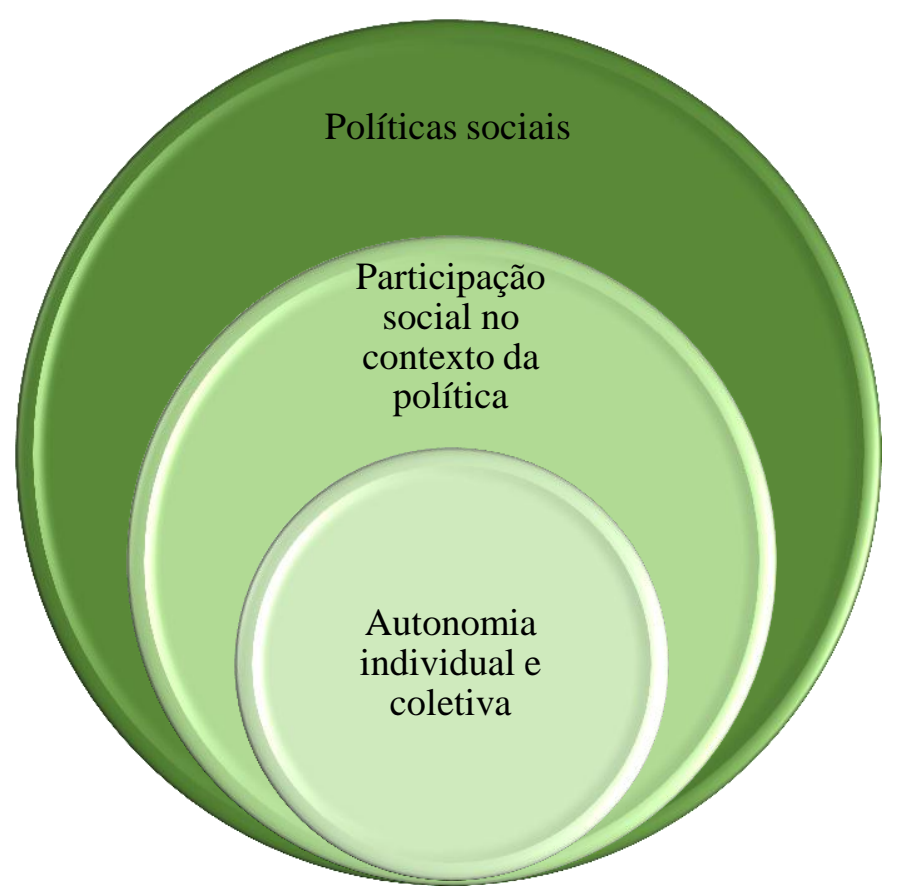

Figura 2- Organização dos temas da dissertação 


\section{CAPÍTULO I. DA POLÍTICA SOCIAL À PARTICIPAÇÃO SOCIAL NO CONTEXTO DA POLÍTICA}

\section{Expansão da bioética para as questões sociais}

Nesse trabalho, a proposta não é achar uma forma de juntar os conceitos de justiça e autonomia ou de harmonizá-los, até porque essa é uma grande dificuldade da própria bioética. A crítica de Clouser e Gert (17) em relação ao uso dos princípios da bioética (beneficência, não-maleficência, autonomia e justiça) parte da argumentação de que esses princípios não seriam guias para a ação, mas nomeações para uma coleção de questões a serem consideradas quando se lida com problemas morais. Além disso, inexiste relação sistemática entre os princípios, muitas vezes conflitando-se entre si, dificultando a resolução desses conflitos, pois não há uma teoria moral unificada da qual todos os princípios derivariam.

Portanto, para os autores (17), os princípios não funcionariam nem como representantes adequados das teorias morais e nem como diretivas ou guias para determinação de uma ação moralmente correta. O uso desses princípios não teria nenhuma similaridade como, por exemplo, o princípio de justiça de Rawls, que realmente serve como uma diretiva de resolução de casos particulares, o que os caracterizam como resumos efetivos de suas teorias. Isso porque, no caso dos princípios da bioética, para resolução de um caso muitas vezes faz-se necessário o uso de dois ou mais princípios que acabam trazendo teorias que competem entre si.

Pelo fato do principialismo não ter unidade sistemática, surgem problemas práticos e teóricos. Como não há uma teoria moral que agrupe todos os princípios juntos, não há diretrizes para ação que sejam coerentes, claras, compreensivas e nem regras para ação ou justificativas para essas regras. Se alguém não explicita a teoria que utiliza, ele não se sujeita aos mesmos padrões que uma pessoa que a explicita. Assim, o principialismo, ao não conseguir operar dentro de uma teoria moral unificada, cai em teorias ad hoc que ofuscam os alicerces e razão morais. (17)

Uma teoria moral adequada colocaria limites em como os profissionais de saúde deveriam agir e apontariam para o fato de que seus deveres não podem ser determinados $a$ priori, mas deveriam ser baseados em aspectos relevantes da cultura e dos costumes. Pode 
aparentar que haja uma incompatibilidade entre uma teoria moral unificada e a aceitação da diferença nos deveres dos profissionais de saúde baseada em práticas e costumes culturais. Nesse caso, a teoria serviria como uma indicação do que é relevante e de colocação de limites, isto é, como um guia no meio das variadas circunstâncias e costumes culturais. (17)

Dessa forma, uma teoria ética adequada não deveria ser apenas alguns princípios e regras sistematicamente relacionados, mas deveria dar uma explicação para nossos acordos e desacordos morais, isto é, deveria organizar nossa forma de pensar moral, deveria organizar nosso julgamento moral, deveria nos dizer o que é relevante para um julgamento moral. O que falta ao principialismo é juntar de forma integrada todos os princípios em uma única teoria, em vez de lançar conceitos de teorias que competem entre si. Essa teoria única deveria pensar em como todos esses conceitos podem se coadunar em suas consequências, em como essas consequências são distribuídas, reconhecer a importância do indivíduo e a centralidade das proibições contra o fazer o mal aos indivíduos.

Para mais além, a teoria ética proposta deveria demonstrar como tudo isso está relacionado, integrados em um sistema claro, criativo e compreensivo que deveria ser usado para resolver problemas morais tanto na medicina como em outras áreas. Deveria proporcionar uma descrição da moralidade que levaria a decisões claras, coerentes e compreensivas para as tomadas de decisão (que não necessariamente levariam a uma mesma decisão, podendo-se ranquear diferentes valores). (17) Posteriormente, Beauchamp e Childress ocupam-se especificamente das críticas de Clouser e Gert e reconhecem que não construíram uma teoria ética fundamentadora, o que provoca o questionamento do que seria uma moralidade comum (52).

Dessa forma, proponho seguir meu trabalho baseando-me na Bioética de Intervenção, que alarga o conceito de bioética, como afirmam Garrafa e Azambuja (18), a epistemologia na bioética deve-se estruturar não apenas de forma pluralista, fundamental para a convivência pacífica, mas de forma multi/inter/trans disciplinar, com variados núcleos de conhecimento e de complexidade, colocando-se a necessidade de se iniciar uma discussão responsável da contradição existente entre o universalismo ético e o relativismo ético. A ideia, portanto, é de trabalhar com ferramentas teóricas e metodológicas mais adequadas e que esteja para além dos quatro princípios anglo-saxões (autonomia, beneficência, não-maleficência e justiça).

Ainda de acordo com Garrafa e Azambuja, temas como direitos humanos, dignidade humana, responsabilidade (individual e pública), vulnerabilidade, integridade, privacidade, 
confidencialidade, igualdade e equidade, não discriminação e não-estigmatização, solidariedade, tolerância e outros, além dos 4Ps (prudência, prevenção, precaução e proteção) entraram na pauta das discussões. Assim, as bases conceituais da bioética devem levar em consideração o relativismo ético, isto é, a não universalidade dos princípios; o respeito ao pluralismo moral; a bioética como ética aplicada; a multi-inter-transdisciplinaridade; a complexidade; e a totalidade concreta. Para que todas essas questões se coloquem como base da epistemologia da bioética, a comunicação e linguagem, a argumentação, o diálogo, a coerência, o consenso e a racionalidade no discurso devem ser fundamentais para a clareza de explicação e entendimento da epistemologia da bioética. (18)

Garrafa (19) afirma que há uma recusa à politização da pauta bioética internacional quando se coloca na agenda bioética o tema da justiça sanitária e se problematizam as desigualdades de acesso aos recursos ou a qualquer assunto que caracterize a qualidade de vida. As razões para essa resistência encontram-se no preciosismo acadêmico que muitas vezes desqualifica o debate sócio-político da bioética, pois a temática política e a inclusão social estariam fora do escopo epistemológico da disciplina; e no conservadorismo de certos pesquisadores, que acreditam que as discussões bioéticas estariam circunscritas ao âmbito biomédico.

Para aprofundamento do tema da discussão social no âmbito da bioética, Garrafa (19) discute três conceitos que embasariam a inserção da bioética no campo social, a saber: empoderamento, libertação e emancipação. Para o autor, empoderamento tem forte ligação com a teoria defendida por Amartya Sen e estaria alicerçada na capacidade de amplificação das vozes de sujeitos vulnerabilizados por questões históricas e culturais, promovendo-se sua inserção social. Dessa forma, o empoderamento não pode estar marcado pelo conceito estreito de autonomia que é defendido pelo principialismo, mas sim em seu reconhecimento como autonomia estreitamente ligada à responsabilidade para com o mundo. Em relação à libertação, Garrafa (19) aponta que ela desvela as posições de poder e permite a pressuposição de uma tomada de posição para a inclusão social. Isto seria feito pela tomada de consciência sobre as forças que oprimem e pela oposição a elas. A emancipação leva ao conceito de um sujeito livre, que tem poder sobre si mesmo. Dessa forma, a inclusão social estaria voltada à compreensão do próprio fenômeno como um processo dinâmico que deve ser levado à prática para o alcance da verdadeira justiça social.

Garrafa e Porto (20), ao defenderem a bioética de intervenção, propõem que os especialistas dos países periféricos - mais especificamente os dos países latino-americanos - 
não devem mais aceitar a despolitização dos conflitos morais que acontecem em seus países. A ação social politicamente comprometida é a única que poderia transformar a práxis social, enfatizando a identidade pública adquirida pela ética. Esta não pode mais ser considerada uma questão abstrata e de consciência que deva ser decidida na esfera da autonomia, como algo que se encontra no foro individual ou íntimo.

A ética começa a ter maior importância aplicada à análise das responsabilidades sociais, sanitárias e ambientais, além das formas de intervenção pública em relação à responsabilidade frente aos cidadãos. Cabe lembrar que ao se pensar em saúde pública, os conceitos de igualdade e equidade devem ser clarificados para maior entendimento, sendo que esta é a consequência daquela, pois equidade seria um ponto de partida. A igualdade, segundo os autores, seria o ponto de chegada da justiça social. (20)

Dessa forma, ao defender uma bioética interventiva, Garrafa (21) coloca que ao longo da história do campo da bioética, o tema de autonomia foi maximizado hierarquicamente em relação à não-maleficência, a beneficência e à justiça, o que fez com que em alguns países a visão individual dos conflitos passasse a ser como a única verdade para sua resolução. Assim, o grande perigo em relação ao conceito de autonomia é este nos levar a um egoísmo exacerbado, anulando as visões coletivas que seriam indispensáveis para se pensar a questão da justiça social.

A bioética latino-americana passa a utilizar de categorias como responsabilidade e alteridade, entre outras, para lidar com questões de políticas públicas em que a tomada de decisão privilegie o maior número de pessoas, mesmo em prejuízo a certas situações individuais; no campo privado e individual, deve-se buscar resolução de conflitos dentro do próprio contexto cultural e social em que acontecem, buscando abordagens pluralistas baseadas nas complexidades dos próprios fatos.

\section{Conceitos fundamentais para se pensar as políticas sociais relacionadas à saúde no contexto ocidental}

A política de saúde como uma política social é um dos direitos inerentes à cidadania (dimensão pública dos indivíduos). O Welfare State, isto é, o Estado baseado no sistema de proteção social, vinculou-se historicamente aos conceitos de um Estado nacional, de uma democracia de massa e do capitalismo industrial. Dessa forma, há três tipos ideais de proteção 
social, em que seus sistemas diferenciados tendem a projetar efeitos políticos em relação à cidadania, o que podem ser altamente diferenciados, de acordo com os valores compartilhados pela sociedade, por suas instituições, se o Estado, sociedade ou comunidade tem maior ou menor peso nas decisões políticas, etc. Em cada contexto particular de uma sociedade, levando-se em consideração as características citadas, emergiria um modelo particular de proteção social. (22)

Assim, partindo das ideias acima, existem as seguintes modalidades de proteção social dentro do contexto de política social ocidental: a assistência social, o seguro social e a seguridade social. Vale ressaltar que cada uma delas tem um impacto particular na construção da sociedade na qual está inserida, gerando condições diferenciadas ao que se entende por cidadania. Para melhor visualização da diferença entre os três sistemas, segue o quadro abaixo (22):

\begin{tabular}{|l|l|l|l|}
\hline & Assistência Social & \multicolumn{1}{c}{ Seguro Social } & \multicolumn{1}{l}{ Seguridade Social } \\
\hline Ideologia & Liberal & Corporativa & Social-Democrata \\
\hline Princípio & Caridade & Solidariedade & Justiça \\
\hline Cobertura & Focalização & Ocupacional & Universal \\
\hline Cidadania & Invertida & Regulada & Universal \\
\hline Referência & Lei dos Pobres & Bismarck & Beveridge \\
\hline
\end{tabular}

Tabela 1 - Modelos de Proteção Social. Fonte: Fleury, S; Ouverney, AM. (2014).

Para uma melhor compreensão, farei um resumo de cada modelo, não me atendo aos detalhes, pois este não é o foco da dissertação.

Em relação ao modelo de assistência social, a ênfase é na autorregulação do mercado, sendo que as necessidades são satisfeitas de acordo com características individuais, baseandose nos valores de liberdade, individualismo e igualdade de oportunidades. O caráter principal desse sistema é compensatório e o grupo aos quais as ações assistenciais são dirigidas estão inseridos no que é considerado pobreza ou grupos vulneráveis, sendo que para beneficiaremse, precisam apresentar provas que não são capazes de adequarem-se à lógica do mercado, necessitando de ajuda financeira. Dessa forma, o fato de receber o benefício do Estado, não os transforma em pessoas de direito, mas demonstra apenas que naquele momento possuem condição de carência suficiente para receber o benefício. Assim, a cidadania invertida seria 
uma relação social em que o indivíduo ou grupo só é objeto da política porque fracassou socialmente ao não se inserir no mercado. (22)

O modelo de seguro social, influenciado por Bismarck, volta-se para os grupos de trabalhadores do mercado formal, já politicamente organizados, nos quais há contribuição obrigatória de empregadores e empregados junto à contribuição estatal. Este seria um modelo tripartite de financiamento, com o intuito de manutenção das condições socioeconômicas dos beneficiários em situações de risco, como a perda de capacidade de trabalho por idade, acidente ou doença. Dessa forma, assegura-se aos que já haviam contribuído durante sua vida de trabalhador, condições parecidas aos de trabalhadores ativos. (22)

Por fim, o modelo de seguridade social tem inspiração no conceito de justiça social ocidental, garantindo a todos os cidadãos o direito de um mínimo socialmente estabelecido. A referência histórica é o Plano Beveridge, de 1942, na Inglaterra, no qual ficou estabelecido que os cidadãos passam a ter assegurados pelo Estado seus direitos sociais. O acesso aos benefícios sociais fica vinculado à necessidade dos indivíduos no qual a redistribuição de benefícios é feita por políticas sociais, buscando-se corrigir as desigualdades geradas pelo mercado. O Estado, portanto, tem papel fundamental nesse modelo, pois grande parte do orçamento público destina-se às políticas sociais, sendo que sua principal característica é uma cidadania universal, com benefícios assegurados como direitos sociais, de forma universalizada. (22)

Para o Brasil, a Constituição Federal de 1988 é um marco ao incluir a saúde como seguridade social, junto com a previdência e a assistência social. Esse é um claro aspecto da introdução da noção de direitos sociais universais como parte fundamental da cidadania e da influência do conceito de welfare state usado no Brasil. Dessa forma, a CF/88 inaugura um novo padrão da política social, que passa a ter caráter de cobertura universal, reconhecimento de direitos sociais, afirmação do poder do Estado, perspectiva publicista de cogestão governo/sociedade, entre outros. (22)

\section{O que vem a ser essa política social?}

Consiste em um termo empregado de forma restrita para se referir a todas as políticas que os governos desenvolvem voltadas para o bem-estar e a proteção social. Em uma concepção mais ampla, a política social abrange todos os meios pelos quais se promove o bem-estar em cada sociedade quanto os determinantes do desenvolvimento social. Neste sentido, deixa de ser uma ação exclusivamente governamental para envolver outros atores sociais. Existem muitas formas de se 
definir política social, por exemplo, de acordo com os propósitos, setores, problemas, processos decisórios, relações de poder e funções. Cada uma delas apresenta vantagens e desvantagens específicas. Uma das definições mais utilizada concebe a política social como conjunto de ações que objetivam a promoção da igualdade e do bem-estar, enfatizando, assim, os valores que guiam tais ações. Este é um aspecto importante porque as políticas sociais são sempre orientadas por valores, embora, em muitos casos, não haja correspondência entre o resultado final e os objetivos iniciais da política. (Fleury e Ouverney. 2014, p. 36).

Dessa forma, temos que a política social envolve o desenvolvimento de estratégias coletivas para redução da vulnerabilidade das pessoas aos riscos sociais. Segundo Kerstenetzky, no Brasil, três mudanças importantes impactaram na forma em que as políticas sociais foram trabalhadas: fim do regime militar no Brasil em 1985 e a redemocratização; esgotamento do modelo de crescimento econômico que remontava à década de 30, caracterizado pela integração subordinada à economia mundial, que depois de um grande período de crescimento entrou em declínio, com inflações galopantes, endividamento externo e interno e sucessivos ajustes fiscais; e o avanço nas políticas sociais entre o ano de promulgação da CF/88 e o ano de 2008, em que o gastos sociais triplicaram, garantindo novos direitos sociais e várias outras prioridades. As inovações que passam a ocorrer com a redemocratização intensificam a universalização do bem-estar e seguem alguns períodos que caracterizam a dinâmica das políticas sociais, conforme quadro-resumo a seguir. (23):

\begin{tabular}{|l|l|l|}
\hline Cidadãos Novos (1988-1994) & $\begin{array}{l}\text { Novo perfil do Estado de bem-estar social, } \\
\text { vinculando políticas de proteção e promoção social } \\
\text { a direitos sociais e princípios universais. }\end{array}$ \\
& - $\begin{array}{l}\text { Dá-se início a novas dinâmicas de descentralização } \\
\text { e participação (universalismo estendido). }\end{array}$ \\
\hline Cidadania e Austeridade (1995-2002) & $\begin{array}{l}\text { Período de maior estabilidade política e diretrizes } \\
\text { mais coerentes para as políticas sociais, mas com } \\
\text { limitado desenvolvimento das políticas sociais, } \\
\text { com modesta evolução do gasto social. } \\
\text { Mesmo com baixo gasto social, as políticas sociais } \\
\text { e o reconhecimento da dívida social apareceram } \\
\text { como primeiro plano da atenção governamental, } \\
\text { com progressos na descentralização das políticas e } \\
\text { na participação, com a instalação de conselhos }\end{array}$ \\
\hline
\end{tabular}




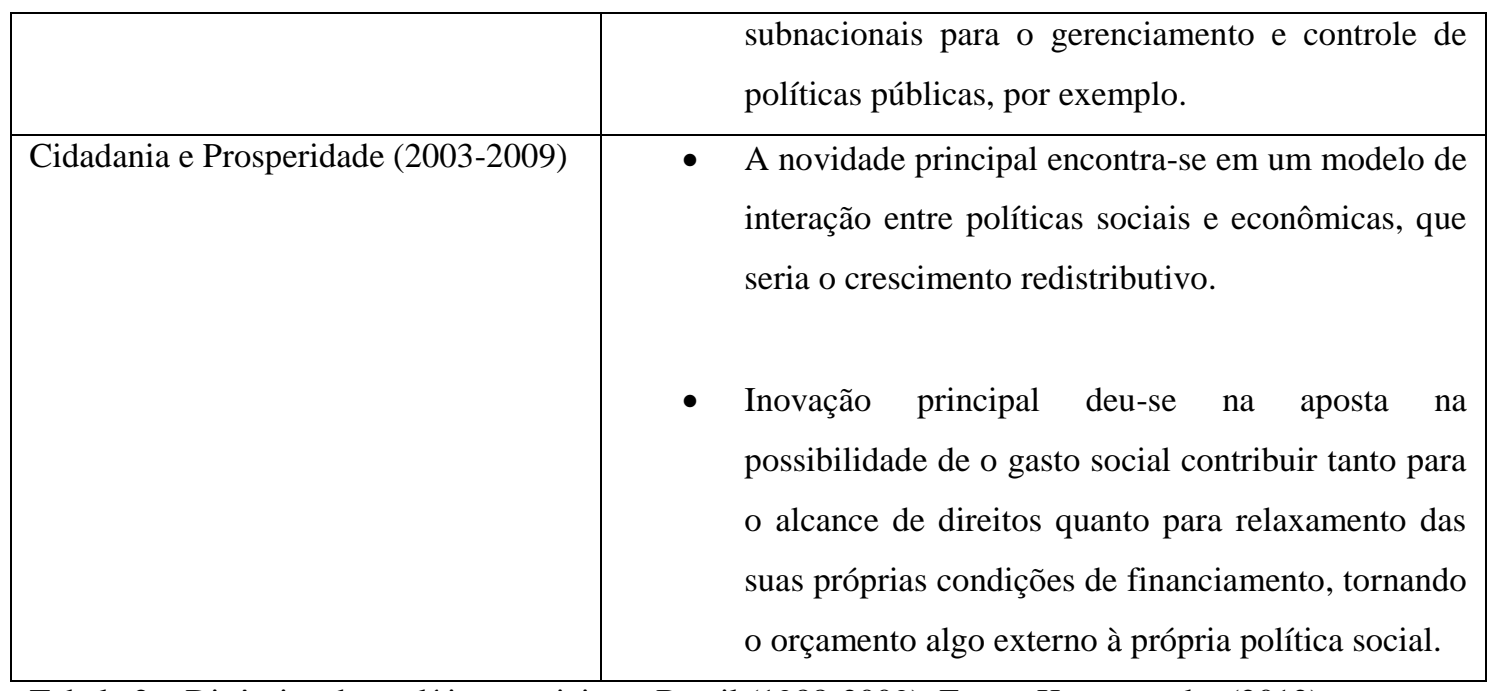

Tabela 2 - Dinâmica das políticas sociais no Brasil (1988-2009). Fonte: Kerstenetzky (2012)

Dentro da discussão do quadro brasileiro das políticas sociais, o drama que o Brasil passa a enfrentar de forma mais vigorosa é o da desigualdade. Portanto, para enfrentamento desse quadro, a ação pública viu-se a trabalhar dentro de um escopo mais amplo, para além do pensamento de combate à pobreza, em que políticas de transferência de renda e outras políticas mais estruturais começaram a fazer parte integrante de um projeto mais amplo de inclusão. Para essa discussão, vale a pena pensar se a política social deveria ser universal ou focalizada. (24)

A focalização, segundo Theodoro e Delgado (24), apesar de ter sido defendida nos anos 90 no Brasil, seria frágil, pois afunilaria a questão social para a órbita exclusiva da política social, transferindo o debate da perspectiva do direito social para o gasto social - o que historicamente acontece no país. Dessa forma, os recursos governamentais destinados às políticas sociais seriam suficientes se bem direcionados (perspectiva da eficiência), a política social seria nada mais que uma política de focalização da pobreza, baseando-se na eficiência alocativa e na eficácia das ações, perdendo seu caráter político e social.

Cabe ressaltar que a $\mathrm{CF} / 88$ surge inovando ao trazer a ideia da política social como instrumento de inclusão social, com políticas universalistas e de extensão de direitos sociais aos mais pobres, resgatando-se, assim, a dívida social. Quando se pensa na política social como prioritariamente focalizada na pobreza, a ideia que se decorre é que somente os pobres teriam direito às políticas sociais, engessando a desigualdade. Assim, quando se recupera a perspectiva universalista ao se falar de política social, as políticas, programas e ações podem ser agrupados em três grupos: 1) aqueles que têm a garantia dos direitos sociais básicos 
estruturados no aparelho do Estado, que seriam exercitados por iniciativa do cidadão, seriam direitos permanentes, independentes de governo e seriam protegidas de cortes orçamentários; 2) aqueles que dependem da iniciativa dos governos por meio de ações e programas temporais nos quais os cidadãos exercitariam seus direitos, com recursos vinculados constitucionalmente, mas não protegidos de corte; e 3) seriam aqueles ligados a situações emergenciais e projetos transitórios. É a partir desse conjunto de políticas - que conjuga, de forma diferenciada, o atendimento a direitos, a garantia de oportunidades e o enfrentamento de carências e de situações de vulnerabilidades sociais - que a política social atuaria como parte de uma efetiva estratégia de combate à pobreza e à desigualdade social. (24)

Na política social de saúde, mais precisamente em sua construção, deparamo-nos com algo que vai além das propostas setoriais econômicas ou políticas, e que reside em macroprocessos sociais que delimitam o campo de expansão dessa política. No caso da saúde vista como direito universal de acesso pelo cidadão, qualquer pensamento que favoreça a noção de saúde como algo que deva ser ofertado pelo mercado e apropriado individualmente restringe o que é uma política universal. Devemos sempre lembrar que o campo das políticas de saúde é atravessado por lutas e enfrentamentos de diferentes forças sociais, sendo que concepções sobre saúde, cidadania, bem-estar, vida, são sempre redefinidos e ganham diferentes significados. (22)

\section{A participação da população nas políticas sociais de saúde no contexto brasileiro}

O conceito de sociedade civil surgiu ou ressurgiu na cena política e social no final do século XX, diferenciando-se do sentido de século XIX ao envolver um sentido tripartite de separação da sociedade civil em relação ao Estado e ao mercado. Além disso, o conceito de sociedade civil reaparece para explicar os processos sociais que estavam ocorrendo nos países da Europa do Leste e nas sociedades latino-americanas. (25)

Fez-se necessário teorizar as novas práticas democráticas desenvolvidas pela sociedade civil brasileira e descobrir suas maneiras de interação com o Estado. Dessa forma, algumas teorias da sociedade civil durante o final dos anos 80 e início de 1990 trataram as práticas dos atores da sociedade civil em um sentido amplo de autonomia, isto é, autonomia como organização do Estado, pois, desde o corporativismo introduzido por Getúlio Vargas nos anos 30, o Estado tinha a prerrogativa de intervir nos sindicatos e associações civis. No entanto, no caso brasileiro, a ideia de autonomia adquiriu contornos próprios e houve um 
trânsito claro entre sindicalismo e associativismo civil, sendo que essa autonomia social não sobreviveu à democracia carregando o mesmo conceito do qual surgiu. Os atores da sociedade civil passaram a interagir em conselhos de políticas e em projetos específicos ligados à implementação de políticas públicas. (25)

Ao migrar do campo para a cidade, a população de baixa renda foi despojada de direitos e alocada nas grandes capitais, ficando com pouco acesso a serviços públicos. Dessa forma, quando os pobres brasileiros passam a se organizar para lutar por serviços públicos, temos aí uma das origens da sociedade civil brasileira. Com o regime militar, o desenvolvimento urbano e as políticas públicas passam a ser vistas a partir de um olhar tecnocrático, tentando integrar atores de classe média em seu projeto de modernização vindo de cima para baixo. O resultado foi a ação de alguns atores da classe média de reação a esse projeto e organização de ações coletivas e associações para disputar esses elementos tecnocráticos. (25)

Outra razão que levou à reorganização da sociedade civil brasileira foi a oposição dos setores liberais e de classe média à ausência de regras e accountability nos processos políticos e civis, transformando a Ordem dos Advogados do Brasil (OAB) em um dos principais grupos de oposição ao autoritarismo. A sociedade civil brasileira ressurge durante meados dos anos setenta, trazendo as seguintes características: a organização dos movimentos populares dos pobres urbanos em níveis locais; a organização do movimento sanitarista por um Sistema Único de Saúde (SUS); o movimento para uma Reforma Urbana Nacional; a organização de membros de associações profissionais, como advogados, médicos, professores universitários, entre outros; e o desenvolvimento de muitas formas de organização no campo brasileiro, incluindo o surgimento do MST. (25)

Outros movimentos surgiram ao longo desse período, como o das feministas e dos negros, ainda que inicialmente não tivessem tanta influência como os movimentos citados acima. No Brasil, o que iniciou essa mudança foi o autoritarismo com que o Estado interveio profundamente na vida cotidiana dos pobres, removendo favelas das áreas centrais das cidades brasileiras e incentivando a migração em massa dos habitantes do campo para as cidades, impossibilitando o acesso à saúde, educação e infraestrutura adequadas. (25)

Nesse período, a principal característica da sociedade civil brasileira foi a reivindicação de autonomia em relação ao Estado e aos partidos políticos, o que levou a autonomia se caracterizar como uma forma de agir sem pedir autorização do Estado e ignorar os limites colocados pelo Estado à organização das associações voluntárias. A autonomia também significou a tentativa de propor formas de administração de políticas sem a 
participação do Estado. Na própria VIII Conferência Nacional de Saúde, havia grupos propondo a organização de serviços de saúde independentemente do Estado. (25)

Dessa forma, podemos dizer que o Sistema Único de Saúde (SUS) tem como um de seus pilares a participação popular, por meio de conselhos e conferências de saúde. A forma de participação da população se deu de forma diferenciada desde os anos 70, no Brasil. Inicialmente, durante a década de 70 , houve o que pode ser chamado de participação comunitária em programas - sua maioria nos próprios serviços de saúde - realizados por agências internacionais na América Latina, no qual a organização autônoma da comunidade era valorizada com o objetivo de se alcançar melhorias sociais. Vale lembrar que esse era um período de ditadura militar, e muitos desses programas foram implementados sem a participação da população. (26)

Em um segundo momento, a participação toma um aspecto mais popular - população excluída socialmente - aprofundando-se a radicalização das práticas políticas que confrontavam o sistema dominante. O centro da participação sai dos serviços de saúde e migram para a sociedade e o Estado, como o objetivo de alcançar a democratização da saúde, com acesso universal e igualitário tanto aos serviços quanto ao poder público. Em um terceiro momento, já na década de 90, ganha força a participação social, recebendo não só a população excluída, mas outras propostas que tomavam força no período: a participação passa a ter o aspecto mais forte de cidadania. Este momento vem na esteira da $8^{\text {a }}$ Conferência Nacional de Saúde (CNS), em 1986, na qual a Comissão Nacional de Reforma Sanitária passa a ser o espeço privilegiado de debate sobre saúde para a Constituinte. Em 1990, o decreto 99.438/90 configura o novo Conselho Nacional de Saúde com ampla representação social. (26)

Vale lembrar que no Relatório Final da $8^{\mathrm{a}} \mathrm{CNS}$, os conselhos municipais despontam como espaços de participação externas ao poder público, de controle, pelos usuários, do sistema de saúde e de todas as etapas de seu ciclo de políticas. O movimento sanitário passa a desenvolver uma intensa articulação social, política e partidária, o que fortaleceu a saúde como direito do cidadão e dever do Estado dentro da CF/88, formalizando legalmente a criação do SUS, regido pela descentralização, integralidade e participação da comunidade. $\mathrm{O}$ SUS regulamenta-se pela lei 8.080/90, sendo que os artigos sobre participação da comunidade e financiamento são vetados pelo presidente Collor, o que levou a um novo processo de mobilização e articulação, culminando na lei 8.142/90, que regulamentou a participação social no sistema de saúde por meio de conferências e conselhos, instituindo o sistema de controle social. (26) 
No âmbito do Ministério da Saúde (MS), foi criada, em 2003, a Secretaria de Gestão Participativa (SGP), que em 2005 se torna a Secretaria de Gestão Estratégica e Participativa (SGEP), com a atribuição de apoiar os conselhos e conferências de saúde, com o objetivo de efetivar a gestão participativa no SUS. Dentro da SGEP existe o Departamento de Apoio à Gestão Participativa (DAGEP) que tem como objetivo apoiar e incentivar a implementação das políticas de promoção da equidade, o fortalecimento do controle social, em parceria com o Conselho Nacional de Saúde e a implementação da Política Nacional de Educação Popular em Saúde. O DAGEP entende que as condições sociais, econômicas, geográficas, de gênero, raça e orientação sexual são determinantes sociais de saúde que orientam o trabalho de promoção de políticas públicas que ajudem a diminuir as diferenças históricas no acesso ao SUS por parte de diversos grupos vulneráveis como as populações Negra, LGBT, do Campo, da Floresta e das Águas, Cigana e em Situação de Rua. (27)

\section{O conceito de justiça nas políticas sociais}

Se as ações sociais visam à promoção da justiça social, elas podem, muitas vezes, gerar conflito entre a busca da equidade - através da garantia e da promoção dos direitos sociais de cidadania - e a escolha das políticas a serem desenvolvidas, as quais podem gerar modos e graus diferenciados de correção dos desequilíbrios sociais. Assim, pensando nas políticas que levam a melhorias setoriais de alguns segmentos sociais e nas diversas regiões do país, elas acabam tendo efeito de aumento das desigualdades, como o processo ocorrido com a situação de saúde no país nas últimas décadas. Observa-se, portanto, um desafio para equilibrar a distribuição e a organização de serviços segundo as necessidades específicas de segmentos sociais. (28)

O princípio da universalidade no acesso aos serviços de saúde torna-se aspecto fundamental, reconhecendo-se a existência de grupos populacionais que não são atingidos pelas ações de saúde, o que requer a organização de diferentes práticas de saúde que permitam a garantia da assistência.

De acordo com Kerstenetzky (29):

A decisão sobre o estilo de política social, se focalizada ou universal, revela-se pouco clara na ausência de uma decisão prévia sobre princípios de justiça social que 
se quer implementar, fazendo, por exemplo, com que se associe automaticamente, e erradamente a meu ver, a universalização com a garantia de direitos sociais e a focalização com noções residualistas de justiça. (2006, p.564).

A autora sugere que o marco em termos de justiça - por exemplo, justiça de mercado ou, alternativamente, justiça distributiva - é crucial para esclarecer nossas atitudes perante estilos de política social. Focalização e universalização apareceriam, então, como métodos alternativos, quando não complementares, de implementação de uma noção de justiça previamente definida. Portanto, segundo argumentos universalistas preocupados com a eficiência social dos gastos sociais, para atingir os pobres mais eficientemente são necessárias políticas universais. Na equidade, a ideia não é simplesmente privilegiar os desfavorecidos, ainda que isso seja necessário, mas arranjar a sociedade e suas instituições para que os cidadãos possam conduzir seus assuntos com apropriada igualdade social e econômica. Dessa forma, a questão passa a ser anterior, de como a sociedade daquele lugar entende o que é justiça social. (29)

Ainda dentro da ideia de Estado e seu conceito de justiça, vale a pena discutirmos o conceito de vulnerabilidade. Jonas (50) situa o conceito no plano ético, onde a vulnerabilidade apela ao dever, ou seja, a uma resposta ética, responsabilizando o outro perante a ameaça de perecimento do existente (ele não se restringe ao humano ou as relações interpessoais), uma vez que, o homem, tal como os demais, é ontologicamente vulnerável, a vulnerabilidade é constitutiva do humano. Desta forma, sendo apenas os homens que detém o poder de destruir todo o existente, compete a ele a responsabilidade de zelar pela vulnerabilidade, de responder de modo proporcional ao seu poder. Assim compreende-se que a vulnerabilidade é ontológica, por isso não pode ser entendida ou utilizada como fator de diferenciação entre pessoas e populações. É uma característica de todo o ser vivente, portanto não pode ser ultrapassada ou eliminada.

Em relação ao que é considerado pessoas em contexto de maior vulnerabilidade no Brasil, os programas de ações afirmativas com enfoques em gênero, raça e etnia são formulados pelo Estado com base em pesquisas que demonstram que as desigualdades na sociedade brasileira levaram determinados seguimentos a se apresentarem mais desiguais que outros. Com o fortalecimento dos espaços de intervenção da sociedade civil nas políticas públicas, os programas de desenvolvimento governamentais passam a valorizar e potencializar os processos sociais existentes, contribuindo para a construção da autonomia dos sujeitos e organizações sociais, requalificando as relações entre a sociedade civil e o Estado. 
Vale lembrar que o PPA referente aos anos 2012-2015 - Plano Plurianal do Planejamento Governamental - demonstra a força da pressão social ao ser decidido colocar como questões transversais dos programas do governo segmentos da sociedade historicamente excluídos. O Relatório do Monitoramento Participativo das Agendas Transversais, publicado em agosto de 2013, ao considerar os temas relativos a públicos socialmente mais vulneráveis, coloca 9 agendas transversais a serem monitoradas: Igualdade Racial, Comunidades Quilombolas e Povos e Comunidades Tradicionais; Povos Indígenas; Políticas para as Mulheres; Criança e Adolescente; Juventude; Pessoa Idosa; Pessoa com Deficiência; População em Situação de Rua; e População LGBT. A figura abaixo demonstra como as políticas sociais setoriais são influenciadas pelas políticas transversais, para além das políticas de saúde: (30)

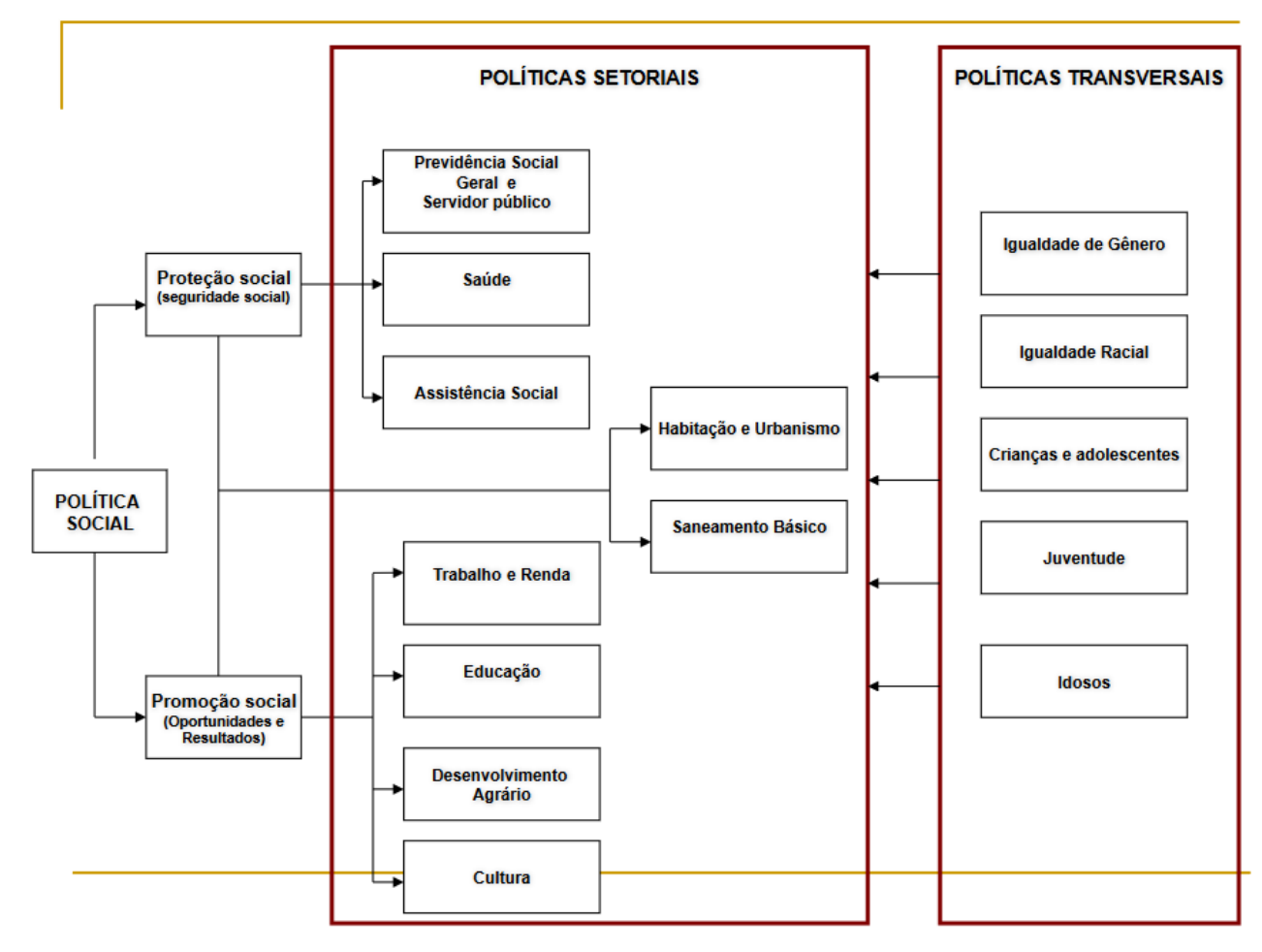

Figura 3 - Organização das políticas transversais no Brasil atual. Fonte: IPEA, 2010.

Com o processo de transversalização das políticas, o que se pode ver é que são colocadas como estratégias as seguintes características da dimensão social:

- Universalização e institucionalização dos direitos da cidadania; e

- Busca da inclusão social das parcelas mais vulneráveis da população. 
De acordo com o Relatório do Monitoramento Participativo das Agendas Transversais (30), estas:

\begin{abstract}
são compostas de compromissos expressos tanto em programas/políticas de caráter setorial (saúde, educação, desenvolvimento urbano, assistência, previdência, cultura, etc.), como em programas/políticas de caráter transversal, que buscam a garantia de direitos de públicos específicos por meio da ação direta e por meio da coordenação das políticas setoriais mais relevantes para atendimento dos públicos.” (2013, p.13)
\end{abstract}

Como se pode ver pelo PPA 2012-2015, as políticas voltadas às populações mais vulneráveis começam a ter visibilidade no contexto da saúde e determinados agravos que afetam esses segmentos começam a ter políticas específicas. Essa situação abre espaço para que a população comece a exigir do Estado a aplicação real da suposta ideia da saúde como direito de todos, sem deixar de lado a ideia de que são indivíduos em meio a uma coletividade, o que acarreta questões complexas nas decisões de políticas públicas em saúde. (30)

Dessa forma, pode-se constatar que a intersetorialidade e transversalidade são como tendências bastante atuais na gestão de políticas sociais, especialmente para governos locais, face à marcada descentralização constitucional. Ressalta-se que a garantia de qualidade de vida não passa somente pela criação de políticas públicas, mas principalmente nas relações que estas políticas estabelecem entre si para atender às necessidades da população de uma determinada área geográfica. (31)

Assim, ainda que seja absolutamente necessário que Governo Federal e Estados também adotem tais princípios, que é o caso da criação de diretrizes mais gerais no plano plurianual federal, o município de fato é quem acaba tendo o papel fundamental na articulação entre sociedade civil, iniciativa privada e as diferentes instâncias governamentais, devendo ser capaz de incentivar a cooperação social na busca de respostas integradas a diversos problemas, incluindo os relacionados à saúde. É preciso que as políticas públicas se ajustem à complexidade da realidade e à "natureza estrutural" dos problemas sociais, para que se possa produzir impacto sobre eles. (31)

Como se pode ver com o PPA formado por programas transversais, proposta de integração das políticas por meio de uma integração intersetorial e interinstitucional no seu desenho, implementação e gestão têm ganhado força, surgindo como uma nova maneira de 
abordar os problemas sociais, para além da segmentação e desarticulação em que usualmente são elaboradas e implementadas as políticas públicas. (31)

Em segundo lugar, devemos focar na análise dos interesses, pois no âmbito das políticas é comum os interesses individuais se sobrepor aos interesses coletivos. É nesta condição de interesse que emerge o papel dos partidos políticos, dos movimentos sociais, dos conselhos de direitos e da própria sociedade que elege os seus representantes. O território local é o espaço privilegiado para realizar a articulação entre as políticas de desenvolvimento urbano e as sociais, pois consideram importante a presença dos sujeitos que são alvo das referidas políticas, bem como a valorização desses sujeitos no atendimento aos direitos sociais por eles demandados. Programas, projetos, equipes técnicas são desafiados ao diálogo, ao trabalho conjunto com a perspectiva da inclusão social. Neste caso, há de se fazer presente a participação dos membros da comunidade envolvida, enquanto sujeitos do processo da continuidade da proposta. (31)

Pesquisa feita pelo IPEA, em 2009, comparando falas e práticas dos planejadores, dos gestores da transversalidade e dos gerentes dos programas transversais demonstra que o conceito de transversalidade, em sentido estrito, pressupõe atuação interdepartamental e criação de fóruns horizontais de diálogo e tomada de decisão, em que conhecimentos, recursos e técnicas acumuladas em cada espaço institucional possam atuar em sinergia. Quando aplicado a políticas para grupos populacionais específicos, por exemplo, o conceito compreende ações que, tendo por objetivo lidar com determinada situação enfrentada por um ou mais destes grupos, articulam diversos órgãos setoriais, níveis da federação ou mesmo setores da sociedade na sua formulação e/ou execução. Como está explícito no conceito de transversalidade, sua aplicação implica desenho institucional que favoreça relações menos marcadas pela hierarquia, pela centralização e que sejam mais aderentes a modelos de gestão lateral, nos quais os atores reúnem-se com interesse de cooperar para alcance de objetivo comum. (32)

No que se refere ao governo federal, a transversalidade surge como diretriz política a ser seguida pelo conjunto da administração no ano de 2003, durante os trabalhos de formulação do PPA 2004-2007, destacam-se os relacionados a segmentos populacionais cujas peculiaridades implicam maior vulnerabilidade à violação de direitos de negros, mulheres, crianças, adolescentes, jovens e pessoas com deficiência. Estes grupos enfrentam dificuldades em ter suas demandas legitimamente incorporadas à agenda pública, tendo acesso a 
oportunidades reduzidas de inclusão e estando mais propícios a ter seus direitos violados. As dificuldades de, como minorias políticas, fazer suas pautas serem incorporadas na agenda pública devido, estão, entre outras razões, ao déficit de representação e ao preconceito. (32)

Com efeito, a prática da transversalidade é vista também como importante estratégia de estabelecimento de alianças intra e extra governamentais em prol de determinadas causas políticas e sociais. Completando esse modelo, conselhos, conferências e demais espaços de articulação com sociedade civil são vistos, em geral, como importantes locais de negociação, visando garantir legitimidade e apoio às campanhas e aos planos. Entretanto, observa-se certo consenso na crítica à capacidade de estes espaços adequarem-se às necessidades da gestão de políticas públicas - em especial no que se refere à tomada de decisão. Isto se daria, na visão de planejadores e gestores, por conta de três fatores: i) do caráter conflitivo inerente a estes; ii) do número de atores participantes; e iii) da inexperiência dos atores com regras e prazos específicos à administração pública federal. (32)

A prática da transversalidade pressupõe estabelecimento de contatos não marcados por desconfiança e competição, já que estas favorecem formação de relações conflitivas e/ou puramente instrumentais. Entretanto, a pesquisa do IPEA demonstrou que é comum a percepção, por exemplo, que determinada secretaria especial possui agenda por demais militante e apartada dos interesses do Estado em determinado tema ou que, determinado ministério não dá a devida importância à questão racial ou de gênero, por exemplo, contrariando diretriz estabelecida pelo presidente da República para determinada questão. (32)

Por trás destas falas, não raro observa-se disputa pelos rumos da política e a importância relativa que a questão da transversalidade nas ações voltadas para minorias deve ocupar em relação a outros assuntos. Nestas situações, é comum que cada ator individual ou coletivo se entrincheire em sua zona de conforto, reafirmando ritualmente a importância de seu tema em qualquer espaço institucional disponibilizado ou, inversamente, evitando ao máximo disponibilizar e/ou participar destes espaços de coordenação transversal. Contando com estruturas bastante enxutas, o perfil do quadro de pessoal das secretarias especiais é formado principalmente por cargos comissionados, com baixo número de funcionários de carreira - o que torna ainda mais agudo o problema da baixa institucionalidade típica de novos órgãos de governo. Dessa forma, os espaços em que temas transversais são discutidos, normalmente exigem perfis de articulação, o que fez com que muitas pessoas da militância referente aos temas começassem a participar do governo e a ocupar espaços na gestão governamental no nível federal. (32) 
Segundo Bourdieu, o campo político pode ser visto como um campo de forças e de lutas, marcado por uma distribuição desigual dos instrumentos de produção de representação do mundo social, sendo que este seria produtor de questões políticas, problemas, programas, análises, comentários, conceitos e acontecimentos que devem ser "consumidos" pelos cidadãos comuns. $\mathrm{O}$ fato de alguns grupos estarem desapossados de instrumentos materiais $\mathrm{e}$ culturais importantes para a participação ativa na política torna o capital político concentrado nas mãos de um pequeno grupo, limitando o universo do discurso político, isto é, do que se é pensável politicamente. (33)

Os agentes dessa luta são por excelência os partidos políticos, que a conduzem mobilizando o maior número possível de agentes com a mesma visão do mundo social e impondo uma representação deste mundo social a um maior número possível de cidadãos, e, ao mesmo tempo, assegurando postos de poder ou não na administração pública. Para o partido não se ver excluído do jogo político e da participação no poder, deve trazer para sua causa o maior número possível de pessoas, alargando sua base. A força das ideias mede-se pela força de mobilização e pela força do grupo que as reconhece. As expressões políticas, programas, promessas, previsões ou prognósticos não são verificáveis ou falsificáveis logicamente, mas são verdadeiros na medida em que quem anuncia (só ou em nome de um grupo) as torna historicamente verdadeiras. Isto depende da capacidade de prever o êxito de suas ações de forma realista e de mobilizar as forças necessárias para isso. (33)

O Estado, portanto, seria uma invenção em que o conjunto de instituições chamadas "Estado" teatralizam o oficial e o universal, dando o espetáculo de respeito público pelas verdades públicas e oficiais em que a totalidade da sociedade deve supostamente se reconhecer (o que não pode haver desacordo porque está inscrito na ordem social em determinado momento). Para o autor, na história da gênese do Estado, um certo número de agentes sociais, que representaram um papel eminente, o construíram progressivamente, isto é, construíram um conjunto de recursos específicos que autorizam seus detentores a dizer o que é certo para o mundo social, a enunciar o que é oficial e a pronunciar palavras que são ordens pois carregam a força do oficial. (34)

$\mathrm{O}$ autor retoma o conceito de obsequium de Spinoza, que seria um respeito ao Estado, à ordem social, isto é, um respeito pela ordem simbólica, e que os agentes sociais de uma sociedade, mesmo os mais críticos, os mais anarquistas, os mais subversivos, demonstram, mesmo que inconscientemente, diante da ordem estabelecida. Dessa forma, a crítica seria uma das armas de confrontação de um regime em relação à sua verdade oficial, demonstrando que 
ele não está conforme o que diz, até porque essa verdade oficial não pode ser considerada nem universal e nem reconhecida por todos, em todos os momentos. Esta verdade tem eficiência e existe em diversos tipos de estrutura, como, por exemplo, em um ministério que trabalha com aspectos sociais, por exemplo, permeados por princípios de igualização, ou de pretensão de igualização. Com todo esse argumento, Bourdieu defende o conceito de Estado por meio de uma proposta de gradação. A noção dual de Estado como Estado/sociedade civil deveria ser vista como um continuum de distribuição de acesso aos recursos coletivos, públicos, materiais ou simbólicos. (34)

Vale ressaltar que hoje em dia há uma corrente de pensamento que afirma a crise da administração pública tradicional e que gerou uma necessidade de muitos governos de transformá-la e modernizá-la. Segundo Brugué, há algumas falácias em torno do que seria administração pública, e uma delas seria que a administração pública seria meramente técnica, onde não haveria disputas políticas e nem ideológicas. Para o autor, a administração é um espaço altamente politizado e é uma pena o fato de que a administração seja invadida por critérios políticos que só serviriam para distorcer o adequado funcionamento da máquina pública. (35)

O pensamento neoliberal, junto com a crise do Estado de bem estar social, sempre coloca que o Estado estaria inchado e a administração pública ineficiente, o que levaria a uma redução do Estado e a modernização da máquina pública. A propaganda tatcherista dos anos 80 apregoava o lema da economia, eficiência e eficácia do Estado, o que reduziria e domesticaria o monstro estatal. Para o autor, a crise desse Estado de bem estar não o levaria a ser o grande culpado, mas a vítima, pois as modernizações de caráter neoliberal transformou a máquina, fazendo com que governo e administração ficasse em uma situação delicada. Portanto, o autor propõe uma invenção de algo diferente para se pensar o Estado, sem racionalizá-lo, porque custos elevados e ineficiências não respondem as exigências de uma sociedade cada vez mais complexa, mais instável e mais diversificada. O objetivo da administração modernizada se concretizaria em sua capacidade de responder a essa complexidade e de incluir a sociedade nessa caracterização. (35) 


\section{CAPÍTULO 2. AUTONOMIA INDIVIDUAL E COLETIVA}

\section{Problematizando o conceito de autonomia individual}

Podemos dizer que a representação simbólica da igualdade, que caracteriza uma classe, é a mesma representação simbólica da diferença, que distingue essa classe. O conceito de habitus de Bourdieu como algo que não é construído, e, sim, constituído na ação, pois há um contexto social mais amplo, e nele os atores vão agir modificando ou mantendo o sistema. Os grupos sociais, com suas diferenças sejam de raça, de sexo, de geração, de gênero etc., também interagem no mundo social, e assim os sujeitos recebem informações de outros grupos sociais, o que pode fazer entrar em conflito; assim se dá uma troca simbólica e a incorporação de novos elementos. (33)

O campo é o espaço que delimita as diferenças e as semelhanças e é, ao mesmo tempo, o espaço onde essas diferenças e semelhanças coabitam e vão medir forças dentro do próprio campo e entre campos. É através da luta social que os espaços são redefinidos e as posições de seus ocupantes são permanentemente redesenhadas. Daí o caráter imprevisível das realidades institucionais vai revelando as suas faces. Repensar e modificar habitus, nesse caso, revela uma nova forma de se posicionar no mundo, não apenas de um sujeito unitário, mas de um grupo com suas diferenças, agora ressignificadas nas relações de interação, cuja ressonância vai implicar na reorganização desses espaços sociais. Afirmar as diferenças, sem dúvida, liberta, mas também oprime, pois, a autonomia individual passa ser uma autonomia de um coletivo, que também passa, no sentido de um grupo determinado, na diferenciação do universal para o setorial. (33)

O compromisso central parece voltar-se para processos de autonomia. Autonomia que não se confunde com o individualismo alheio ao social, nem com a alienação de sujeitos em função de seu grupo, mas uma autonomia que impulsiona o Estado a revisitar valores, competências e processos específicos que se afirmam enquanto portadores de demandas diferenciadas. Uma vez explicitadas as diferenças, abre-se o campo da negociação das contradições que passa pela análise crítica de práticas instituídas, até uma possível reformulação dessas práticas. (33) 
Segundo Sancho, entende-se por autonomia, normalmente, a capacidade de reger-se por uma lei própria e de tomar decisões por si mesmo, sem deixar-se influenciar pelos outros. A capacidade de sermos responsáveis por nossos próprios comportamentos e de conduzir a nossa própria vida, de acordo com nossa própria consciência. Autonomia, dessa forma, equivaleria à liberdade, sabendo-se que, desde o princípio do conceito de autonomia, a ordem da natureza foi sobrepassada pela ordem da razão moral, que é entendida também como vontade racional. Nessa visão, o modo de entender o que significa autonomia depende do modelo e do tipo de conceito de razão com a qual está conectada. Para os gregos, o conceito de autonomia era uma categoria política central. A autonomia sempre foi, desde meados do século V a. c., a meta das cidades gregas, em que buscavam preservar certa independência, especialmente em relação ao direito de poder determinar seus próprios assuntos internos. (36)

Ainda que os gregos usem o conceito de autonomia, na maioria das vezes, em seu sentido político, também pode-se observar, mesmo que esporadicamente, em sentido ético. Foi com a teoria kantiana que a autonomia alcançou um conceito de ampla relevância filosófica: a possibilidade de o ser humano determinar-se a si mesmo por si mesmo em virtude de sua capacidade racional. A autonomia, no sentido de autolegislação mediante a razão, pode ser entendida como princípio estrutural da filosofia kantiana. O homem, como ser racional, tem a possibilidade de atuar independentemente do mecanismo de causalidade natural e conformar suas ações ao princípio da autonomia da vontade pura, isto é, realizá-las livremente. (36)

Kant abriu uma nova perspectiva nascida no século XVII: a crença em que todos os indivíduos são capazes de conviver sujeitando-se a uma moralidade de autogoverno, em que todos tenhamos igual capacidade para perceber por nós mesmos os mandatos da moral e que seríamos capazes, igualmente, de atuar de acordo com eles. Trata-se da visão de um novo modo de vida, produzido por a mudança social moderna, uma nova forma de nos entendermos como agentes morais. (36)

A crítica genealógica de Nietzsche transformou a razão pura em impura, seguindo o fio condutor do corpo humano. Não há renúncia da razão, mas esta é vista como uma razão radicada no corpo e transformada desde sua raiz vital por seu caráter criativo, transvalorador e interpretado. A existência humana tem um caráter perspectivista e interpretador, sendo que a perspectiva constitui um caminho libertador frente a todo dogmatismo. O ponto de partida das perspectivas e dos ensaios libertadores é o corpo. Trata-se de um indivíduo autônomo 
"supraético", segundo Nietszche, porque autônomo e ético se excluem, dado que o indivíduo verdadeiramente autônomo e independente está acima da eticidade, vivendo a plenitude de uma liberdade mais além da eticidade dos costumes e das exigências modernas. $\mathrm{O}$ perspectivismo nietzschiano continua em relação ao kantiano até chegar em uma nova raiz, mostrando que a capacidade autolegisladora, que constitui a própria soberania, é uma força de autodeterminação, uma liberdade da vontade. (36)

Sancho, ao trazer o conceito de ética da razão cordial de Cortina, admite que a interação comunicativa e a compaixão permitiriam manter a autonomia por meio do processo de reconstrução social do reconhecimento recíproco que leva em consideração a compaixão. Dessa forma, não devemos apenas afirmar que a autonomia obriga, mas também obriga a coautonomia que gera o dinamismo do que a autora chama de razão cordial do reconhecimento recíproco e da compaixão. A autonomia seria a capacidade de dar-se leis a si mesmo e a viver segundo elas. Para além da independência, a liberdade como autonomia consiste em capacidade de se auto obrigar a cumprir as leis que as pessoas produzem para si mesmas. Essas leis deveriam ter um caráter de poderem ser convertidas em leis da humanidade, isto é, leis morais, mas para isso seria necessário a existência de um certo ideal de humanidade que todos se sentissem vinculados. Não se trataria, entretanto, de uma autonomia ideal e transcendental no âmbito da autoconsciência, mas de uma autonomia real, na qual a razão se arraiga ao coração e onde a obrigação moral está vinculada ao sentimento de respeito pela dignidade e a compaixão cordial ligada ao vulnerável. (36)

Pensando nos movimentos sociais e na construção das autonomias coletivas, os conceitos tradicionais das ciências sociais, no entanto, tornaram-se insuficientes para a explicação da pluralidade de novos movimentos sociais. As identidades coletivas passaram a ser compreendidas a partir não só de um agregado de interações sociais, mas também da razão político-estratégica de atores sociais que fazem parte desses espaços. Santos busca no trabalho sobre memória coletiva, mais precisamente utilizando Halbwachs em sua análise, uma forma de mostrar as associações entre as dimensões individuais, sociais e políticas. A afirmação central de Halbwachs sobre a memória é a de que, quaisquer que sejam as lembranças do passado que possamos ter - por mais que pareçam resultado de sentimentos, pensamentos e experiências exclusivamente pessoais —, elas só podem existir a partir dos quadros sociais da memória. Dessa forma, a individualidade não se contraporia a quadros sociais se a pensarmos como construção, isto é, como um processo de apropriação de representações coletivas por parte do indivíduo em interação com outros indivíduos. (37) 
Os quadros sociais da memória não são constituídos pela combinação de lembranças individuais, nem mesmo de formas vazias, mas, ao contrário, são os instrumentos de que a memória coletiva se serve para recompor uma imagem do passado que se combina, a cada época, com os pensamentos dominantes da sociedade. Assim, lugares da memória apresentam um poder - fixo em pedras, monumentos e construções arquitetônicas, mas presente também em rituais e comemorações - capaz tanto de impor a representação de um grupo sobre outros, quanto de abrir um espaço para que grupos oprimidos possam fortalecer suas identidades através da recuperação de traços da memória. Assim, afetividade, emoções, características individuais, repressões e intenções, todos estes, seriam aspectos que poderiam ser compreendidos apenas em relação às determinações sociais, tornando-se impossível para qualquer abordagem escapar à questão da subjetividade e das marcas de seu próprio tempo.

Para alguns autores, a derrocada do welfare state demonstra fim dos grandes movimentos coletivos, remetendo-nos uma individualização do fazer político. A exacerbação do individualismo convive, nas sociedades modernas, com uma miríade de valores contraditórios. Pensando o espaço público como inversamente proporcional ao espaço subjetivo do indivíduo e que os indivíduos devem relacionar-se em sociedade, acaba ocorrendo que os grupos sociais midiáticos realizam a mediação social através de instâncias desligadas dos espaços sociais coletivos tradicionais. As sociedades modernas passam a ser lugares onde o coletivo gradativamente assume contornos individualizados. Para Bourdieu, é impossível dar sentido a um todo que escapa ao próprio sujeito, histórico, determinado socialmente, imerso em um universo social fora de nossos controles. (38)

As velhas identidades tiveram um declínio do século $\mathrm{XX}$, fazendo surgir novas identidades, de forma que fragmenta o indivíduo, que até então era visto como um sujeito unificado. Vale ressaltar que o conceito de identidade é bastante complexo, mas não se pode negar a mudança estrutural que vem ocorrendo nas sociedades modernas, nas quais os conceitos de classe, gênero, sexualidade, etnia, raça, nacionalidade, que forneciam sólidas localizações de indivíduos sociais, agora começa a ter características de fragmentação, mudando as próprias identidades pessoais. Esse duplo deslocamento, de descentração tanto de seu lugar no mundo social e cultural quanto de si mesmos, constituiria uma crise de identidade para o indivíduo. Como os sistemas de significação e representação cultural vão se multiplicando, nos vemos frente a uma multiplicidade de identidades possíveis, com cada uma das quais poderíamos nos identificar, mesmo que temporariamente. (39) 


\section{Alargando o conceito de justiça social e pensando a autonomia coletiva}

Baseando-se na bioética de intervenção, que se coloca em um contexto de uma bioética social, há a estrutura na repolitização de conflitos morais, colocando-se do lado dos mais vulneráveis. Seu local de discussão é o sul e desde o sul há um questionamento e uma reflexão sobre o contexto da justiça que, apesar de não haver uma teorização sistemática de justiça social nas bases da bioética de intervenção, há uma abordagem dialética com relação ao tema na forma da injustiça. Dessa forma, a busca por justiça social estaria vinculada ao combate às inequidades sociais e se ancoraria, principalmente, na teoria de Amartya Sem, que difere da perspectiva de justiça baseada no principialismo, que, por sua vez, tem suas bases liberais, no qual há a primazia da autonomia sobre a justiça, afirmando a superioridades dos direitos e liberdades individuais sobre os coletivos.

Assim, a justiça não deve ser vista como aplicação de norma, mas sim como um núcleo significativo que possibilita o ordenamento das relações sociais e da interação humana dentro de uma sociedade. A justiça seria o vínculo que une a ética e a política, pois esta é ética quando tem como horizonte o bem da sociedade, sendo que a ética não poderia ser vista apenas como conduta moral - que no caso seria pura liberdade individual -, mas como fundamento mesmo da sociedade. No fundo desse debate coloca-se a necessidade de se reconstituir o social baseado nos princípios comunitários, em oposição ao atomismo social que caracteriza as sociedades modernas; assim como a busca de um bem comum, capaz de criar horizontes de significação coletivos para o exercício da liberdade e tomada de decisões, em oposição ao egoísmo. (40)

A ideia é que as pessoas se fazem humana através de outras pessoas, desprendendo-se uma visão comunitária que assenta a comunidade como base do ser, do existir e da realização de todos os seres humanos. Seguindo o pensamento do filósofo moçambicano Ngoenha, o autor coloca que a verdadeira questão de hoje é conceito de justiça e a pergunta que se coloca paira em torno de como converter a injustiça humana em direitos humanos. Dessa forma, a contribuição do conceito de ubuntu como justiça restaurativa, que tem enfoque muito maior na restauração da dignidade humana do que no castigo emanado pelo conceito de justiça, deuse tanto pelo fato de ter se ocupado com as questões do mundo negro (escravidão, emancipação política, entre outras) quanto pelo próprio conceito de justiça restaurativa, que alarga o conceito de justiça para além do continente africano. (41) 
Partindo do pressuposto que no Brasil a justiça sanitária faz parte da agenda bioética e esta se baseia no debate sócio-político que inclui temas de saúde pública e coletiva, como a inclusão social, por exemplo. A proposta é que o princípio justo da proteção se transforme em uma epistemologia de cunho abrangente com o objetivo de suprimir as desigualdades. $\mathrm{O}$ autor analisa as expressões empoderamento, libertação e emancipação que serviriam como embasamento para se sustentar a intervenção bioética no campo social. A primeira vincula-se fortemente a Amartya Sen, em que a ideia de empoderamento de sujeitos individuais, vulnerabilizados por conta do próprio processos histórico e da cultura na qual vivem, atua como algo que amplifica as vozes desses sujeitos, buscando-se a inserção social desses sujeitos. (42)

Dessa forma, a humanidade é conferida aos seres humanos quando do processo coletivo, isto é, na produção e reprodução contínuas dos significados atribuídos às práticas sociais. A proposta da bioética de intervenção passa pelo pressuposto que uma ação social politicamente comprometida é a única capaz de transformar a práxis social. Para além disso, a BI coloca o corpo como parâmetro de intervenção ética, pois a partir dele a visão de empoderamento unifica os indivíduos sustentando o processo de produção e reprodução social e a coletividade na qual essas pessoas vivem. Portanto, a ideia de empoderamento salienta que as escolhas dos sujeitos sociais não podem ser vistas a partir de um conceito de autonomia individualista, mas uma forma em que esta deve ser vista em relação à responsabilidade, isto é, ela deve estar ancorada na interconexão entre os seres humanos e todas as formas de vida.

A proposta de Brugué (35), ao pensar a modernização do Estado e da máquina pública, considera a fragmentação e polarização da sociedade hoje em dia, que se caracterizaria por uma extrema diversidade e de uma dificuldade em encontrar um equilíbrio. Dessa forma, os objetivos instrumentais de economia e eficiência tornar-se-iam objetivos substantivos de inclusão e equilíbrio para que se modernizasse a administração pública. No Brasil, por exemplo, temos o movimento da nova gestão pública, lançada como proposta em 1995 no Plano Diretor de Reforma do Aparelho do Estado (PDRAE), pensado por Bresser Pereira e equipe, mas que não foi totalmente implantado no serviço público do país. (43)

De acordo com Cortina (44), hoje em dia há um movimento comunitário que defende uma democracia radical baseando-se na ideia de que a dignidade da política coincide com a totalidade da vida social humana: 
O homem é um ser dotado de razão e de fala (animal social) que apenas em sua forma perfeita de comunidade social (comunidade política) pode alcançar a perfeição e a felicidade. (2012, p.13)

Para esse grupo, democracia significa nada além de governo do povo e já que este se baseia na isonomia (igualdade entre os cidadãos), a democracia radical exige a participação direta de todos os cidadãos na tomada de decisões. Esse tipo de pensamento também tem muitas limitações, como exemplo a confusão entre o social e o político: o Estado se definiria como universal e a sociedade civil seria o espaço de interesses particulares em conflito. (44)

Dessa forma, o político acaba recebendo uma dignidade própria ao ser identificado com o universal e, consequentemente, com o ético, pelo seu próprio caráter universal. O ideal para o ser humano seria chegar a ser um cidadão, participando da comunidade política, que se confunde com a comunidade ética. A autora chama essa identificação entre o político, o social e o ético de "imperialismo político", que permite a intervenção da política em todos os setores da sociedade civil, como se estes fossem menores de idade em matéria de aspiração ao universal. (44)

Para Cortina, seria possível pensar que em diversos âmbitos da vida social seja inevitável organizar-se de forma representativa, mas isso não pode ser empecilho para que outros campos se organizem de maneiras diversas, até porque a homogenização mataria a peculiaridade de diversas atividades que não devem ser vistas como idênticas, mas apenas como atividades humanas diversas. (44)

Há atualmente uma insatisfação por conta da escassa participação nos assuntos que afetam a todos e que vem gerando uma multiplicidade de exigências éticas na vida social, como pode ser visto nas éticas aplicadas, que têm em comum a necessidade e o desejo de que em distintos campos as pessoas afetadas pelos diversos temas tenham não só a última palavra, mas algo além disso. Assim, o tipo de democracia radical que a autora trabalha parte do pressuposto de que a organização política é uma das formas inevitáveis da organização social. Portanto não cabe exigir sua eliminação, mas conseguir que a forma política seja legítima e que os procedimentos de tomada de decisão garantam ao máximo resultados justos. (45)

Para Cortina, a democracia radical seria a que, respeitando a diversidade das facetas humanas e das esferas sociais, reconheceria seus compromissos no campo político e empenharia-se em cumpri-los, abandonando a vontade de colonizar outros âmbitos. Os seres humanos, assim, são interlocutores válidos e devem ser tomados em conta dialogicamente. 
Ainda segundo Cortina, nas sociedades que mudaram de visão moral única para o pluralismo a questão que se coloca é de como criar uma intersubjetividade ética. Nas sociedades pluralistas as religiões tradicionais oferecem seus diferentes pontos de vista, que são perspectivas que competem entre si. (45)

Assim, para aplicar os princípios éticos em um contexto concreto, é indispensável que se entenda o significado de cada princípio, isto porque os princípios são universalmente válidos não em seu sentido absoluto, mas ao interpretá-los e generalizá-los para uma aplicação em um contexto social (isto não é relativismo, mas pluralismo). O pluralismo de interesse, como uma terceira forma de pluralismo, caracteriza-se por ser político, econômico e profissional. Interesses políticos são claros na bioética porque faz parte legislar ou decidir sobre questões bioéticas, sendo que partidos políticos defendem posições que não são apenas morais ou políticas, mas acabam tornando-se partidárias. (45)

Muitas ideias defendidas por cidadãos são monopolizadas por partidos políticos e os cidadãos acabam sendo acusados de usarem o discurso do partido, como se estes não tivessem a habilidade de pensarem e decidirem por si só. Para a autora, é letal que um partido capitalize uma posição moral e a considere como dele, sendo que a sociedade civil que deve discutir assuntos morais e tomar decisões quanto aos temas. A vida moral não deve ser partidária, porque torna-se um arsenal de disputas de votos entre quem quer o poder. Decisões morais que afetam sociedades pluralistas têm sido tomadas a partir de uma ética cívica transnacional nascente, que tem como proposta o empoderamento das pessoas e como princípios, uma proposta de maior aplicabilidade à prática. (45)

Dessa forma, é impossível entender o significado que está por trás desses princípios simplesmente pensando sobre seus fundamentos éticos. A autora coloca as seguintes questões: quem é responsável por interpretar os princípios no processo concreto de tomada de decisão? Quem é legitimado a tornar essas decisões vinculantes? Isso demonstra a dificuldade que a ética passa ao tentar ser considerada intersubjetiva e não se identificar nem com a lei nem com religião. Por mais que as leis pretendam ser adequadas moralmente, nas sociedades pluralistas alguns grupos podem não as considerar adequadas. (45)

A questão que se coloca é que no mundo da ética não há representação e a eleição de representantes para promulgar leis morais seria em si contraditório: se uma pessoa não se afilia ou reconhece algo como moralmente obrigatório, ela não se vê obrigada a cumprir com determinada lei. Dessa forma, o diálogo é fundamental para chegar-se a acordos relativos às 
obrigações éticas. Portanto, não há parlamentos éticos, nem igrejas éticas, nem tribunais éticos, mas há uma obrigação moral diferente da obrigação legal. Então, a autora se questiona quais seriam as esferas que formariam julgamentos morais e quais entidades seriam legitimadas a fazer julgamentos morais. Para a autora, a opinião pública seria um dos possíveis laboratórios do julgamento moral. (45)

Cabe-nos pensar, a partir da bioética, o que seria a ética aplicada no mundo atual. Para Cortina, não basta apenas refletir sobre como aplicar os princípios éticos a cada âmbito concreto, mas temos que levar em conta que cada tipo de atividade tem suas próprias exigências morais e proporciona seus próprios valores específicos. Não podemos simplesmente fazer a aplicação mecânica dos princípios éticos aos diferentes campos de ação, mas antes analisar quais são os bens internos que cada um deles traz para sociedade e quais valores e hábitos são necessários para alcançá-los. A ética aplicada deve ser interdisciplinar e deve considerar qual o seu método próprio (como ela se relaciona com princípios éticos e decisões concretas), quais são seus valores cívicos e quais seriam os valores próprios de cada atividade. (46)

A autora propõe um novo modelo de ética aplicada como hermenêutica crítica, o que quer dizer que ela não é nem dedutiva e nem indutiva, circulando entre os diferentes âmbitos da vida social como um princípio ético que se modula conforme o âmbito em que ela esteja inserida. Um só modelo de ética seria impotente para orientar todas as decisões relacionadas aos mundos político, econômico, ecológico, médico, ou a própria convivência entre os cidadãos. A ética passa a ser vista não mais de uma forma individual, mas coletiva, nos quais a saúde, a economia, as instituições sociais, teriam como raiz profunda as atividades sociais, realizadas por seres humanos e se estruturaria moralmente por metas sociais, por mecanismos adequados para alcançá-las e por estar expressa na constituição e na legislação. Além disso, ela deve estar no âmbito da ética civil, que é o conjunto de valores que os cidadãos de uma sociedade pluralista compartilham, independente da concepção do que seria uma vida boa. Deveriam ser levadas a sério questões como liberdade, igualdade e solidariedade junto com atitudes de tolerância e predisposição ao diálogo. (46)

Ao pensar na ética e na educação moral democrática, cabe-se pensar as habilidades técnicas e sociais aprendidas na escola serão suficientes para que um indivíduo em uma sociedade ocidental possa defender-se e triunfar na vida. Caso levemos a sério os valores que inspiram a pretensa sociedade democrática de liberdade - aqui entendida como autonomia -, igualdade, solidariedade, aprendidos de uma forma técnica, então nossa sociedade cumpre um 
papel de ensinar instrumentalmente esses valores, o que não assegura que essas pessoas sejam formadas autonomamente com desejo de autorrealização: (46)

\begin{abstract}
No contexto de uma democracia moderna, a autonomia deve ser entendida ao mesmo tempo como liberdade negativa e como liberdade positiva no sentido que Isaiah Berlin confere a esses termos, ou seja, o direito de usufruir um espaço de livre movimento, sem interferências alheias, no qual cada um possa ser feliz a sua maneira, e também o direito de participar ativamente nas decisões que me afetam, de modo que na sociedade em que vivo possa ver-me como legislador, como interlocutor válido na elaboração das leis. (2013, p. 130).
\end{abstract}

Para se pensar sobre a questão da autonomia coletiva, Scott busca pensar o feminismo em relação aos termos de pluralidades e diversidades em vez de universalidades. A autora buscou uma teoria que quebrasse o pensamento ocidental que divide o universal ligado ao masculino e as especificidades ligadas ao feminino, hierarquizando-as. A autora propõe o uso do pós-estruturalismo, que tem como conceitos importantes a linguagem, o discurso, a diferença e a desconstrução. Em relação à linguagem, seria um sistema de significações e a teoria pós-estruturalista ajudaria a entender como ele funciona, como as instituições se organizam, como as relações de produção são experienciadas e como a identidade coletiva é estabelecida. Em relação ao discurso, como no pensamento de Foucault, discurso não é apenas linguagem ou texto, mas uma estrutura histórica, social e institucional feita de termos, categorias e crenças. Envolve-se, na elaboração desses significados, conflito e poder. O conceito de diferença segue o pensamento de Saussure, e leva em consideração que o significado é feito por meio de contrastes implícitos e explícitos, que uma definição positiva está ligada ao seu oposto, como se fosse um material reprimido. (47)

Seguindo Derrida, este diz que a filosofia ocidental foi construída por oposições binárias: unidade/diversidade; identidade/diferença; universalidade/especificidade. Desconstrução é um conceito caro para Derrida e seria o reverso e o deslocamento das oposições binárias. Um conceito importante para o feminismo é diferença e identidade, que apesar de parecerem binômios antonímicos, essa antítese esconde a interdependência dos dois conceitos, até porque igualdade não é a eliminação da diferença e diferença não retira a igualdade. A proposta da autora é criticar esse binarismo até chegar ao entendimento de como esses conceitos coagem ou constroem significados específicos. Tomando como ponto de partida o caso Sears, a autora defende que quando diferença e igualdade são colocadas de forma dicotômica, não há uma escolha possível. Para o período, entretanto, as feministas não poderiam deixar o tão caro conceito de diferença de lado, mas, segundo a autora, deveriam 
levar em consideração o conceito de igualdade para falarem dos princípios e valores do sistema político vigente. (47)

Assim, a autora se pergunta: "Como então podemos nos reconhecer e usar noções de diferença sexual e ao mesmo tempo fazer argumentos de igualdade? ". Para a autora, as únicas respostas a essa pergunta são: 1) desmascarando a forte relação construída ao opor igualdade como antítese da diferença; e 2) a recusa da construção dicotômica nas escolhas políticas. A diferença, dessa forma, presume que um acordo social feito nesses termos deve considerar pessoas diferentes como iguais (não idênticas) para um certo propósito, sendo que assim o oposto de igualdade é desigualdade (inequidade). A antítese da diferença mais usada é a identidade ou sameness, sendo que nesses casos contexto deve ser especificado. A autora coloca que dentro da categoria "feminino", as mulheres tipicamente participam de muitas formas de "comportamento" masculino e que socialização é um processo complexo que não produz escolhas uniformes. A oposição masculino/feminino serve para obscurecer as diferenças entre as próprias mulheres no comportamento, natureza, desejo, sexualidade, subjetividade, identificação de gênero e experiência histórica. Dessa forma, a alternativa para essa construção binária da diferença sexual não é sameness ou identidade entre homens e mulheres, mas uma diversidade historicamente complicada do que a permitida pela binariedade (mulher $\mathrm{x}$ homem). A igualdade construída em cada lado da oposição binária esconde a multiplicidade da diferença e mantém sua irrelevância e invisibilidade. A única alternativa seria recusar a oposição entre igualdade e diferença e insistir nas diferenças diferenças como condição das identidades individuais e coletivas, diferenças como um desafio constante para essas identidades, história como uma repetida ilustração das diferenças e estas como o significado último da igualdade. (47)

Outro ponto importante é a solidariedade, como deve existir em uma verdadeira democracia, consiste em uma atitude pessoal de fortalecer a rede que une os membros de uma sociedade e por uma atitude social que fortaleça os mais fracos, buscando uma igualação na qual todos possam exercer sua liberdade. Para isso, é necessário se pensar uma educação moral em que o jovem deve formar seu caráter individual, fortalecendo o autoconceito visando melhorar a autoestima. Além disso, a moral deve buscar a felicidade, que deve ser entendida de várias maneiras, pois em uma sociedade pluralista e democrática, o educador não deve apregoar seu próprio modo de ser feliz como universalizável, mas ensinar que a felicidade é um dom e a vida pode ser enfrentada com elevado Estado de espírito. Outra possibilidade é a moral em seu sentido coletivo, comunitário, que faz o indivíduo se sentir membro ativo de uma comunidade onde são manifEstados nossos costumes, nossas normas 
legais e instituições que formam nosso ethos comunitário. Para além da nossa comunidade, a solidariedade deve ter seu caráter universalista, que permite o questionamento até mesmo das normas comunitárias a partir de uma consciência moral que é capaz de se colocar no lugar de qualquer outra pessoa. (46)

Segato, ao falar sobre alteridade e ética no movimento de expansão dos direitos universais, propõe que a lei deve mediar e administrar a convivência de comunidades morais distintas. Se a lei adere a uma única tradição, a um único código moral particular sob a administração de um Estado nacional, isso se configuraria um localismo nacionalizado. No ocidente, as concepções de justiça e de direitos próprios fizeram com que os direitos humanos desmoralizassem a diferença, na forma de uma fobia ao outro, fazendo com que a superioridade moral fosse o capital simbólico de maior peso ao se exercer a dominação. A preocupação deve girar em torno do fato de que relatividades internas podem levar à fragilização da coletividade, colocando diferentes perspectivas dentro de um mesmo grupo, o que levaria a se pensar para além da resolução de conflitos, mas a transformação do conjunto da sociedade que compõe essa coletividade. (48)

Segato trabalha com o conceito de pulsão ética, que nos permitiria abordar criticamente a lei e a moral, considerando-as adequadas ou não. Ela permitiria o afastamento da cultura que nos viu nascer, ajudando na transformação dos costumes das comunidades morais nas quais vivemos. O que nos torna humanos não é o fato de sermos membros natos e cômodos de nossas comunidades morais, mas antes por sermos históricos e não respondermos a uma programação determinista que nos forma dentro da moral ou da lei. Dessa forma, a moral e a lei seriam substantivas, enquanto a ética seria pulsional e inquieta. $\mathrm{O}$ anseio ético seria universal na medida em que pode ser encontrado dentre membros de qualquer grupo humano, claro que considerando seus objetos variáveis, o que caracteriza a ética como o lugar de não haver conteúdos listáveis. A consciência moral, portanto, reconhece a culpa enquanto a consciência ética reconhece a responsabilidade, respondendo ao outro, admitindo sua interpelação. (48)

\section{O conceito de responsabilidade}

Iniciarei essa parte buscando a escrita de Judith Butler, em seu livro "Relatar a si mesmo, crítica da violência a ética", no qual a autora situa a questão da filosofia moral, mais precisamente as questões morais, como questões que surgem no contexto das relações sociais, 
mudando de acordo com o contexto. Ao citar Adorno, Butler vai além ao dizer que as questões morais sempre surgem quando as normas morais de comportamento deixam de ser autoevidentes e indiscutíveis na vida de uma comunidade. Dessa forma, o ethos coletivo seria conservador e traria uma falsa ideia de unidade que tenta suprimir as dificuldades relativas ao ethos contemporâneo, pois a partir do momento que o Estado da consciência humana e o Estado das forças sociais de produção abandonaram as ideias coletivas, essas mesmas ideias passam a ter qualidade repressoras e violentas, mantendo sua aparência de coletividade. A ideia de violência aqui seria em relação à ética no contexto de pretensões de universalidade, e o surgimento de questionamentos morais leva a divergências entre o interesse individual e o interesse universal, onde o universal deixa de concordar com o individual ou de inclui-lo, fazendo com que a própria pretensão de universalidade ignore os direitos dos indivíduos. As questões morais surgem apenas quando o ethos coletivo já não impera mais, o que demonstra uma tensão entre ethos e moral, pois aparentemente o enfraquecimento daquele é a condição para o aperfeiçoamento desta. (49)

Ainda seguindo o pensamento de Adorno, a autora diz que uma norma ética que não ofereça um modo de vida ou que não se revele dentro das condições sociais existentes como algo impossível de ser apropriada, então ela deve ser submetida a uma revisão crítica: (49)

se ela ignora as condições sociais, que também são condições sob as quais toda a ética deve ser apropriada, aquele éthos (sic) torna-se violento. (2015, p. 16)

Para Butler, o problema não é a universalidade em si como violenta por definição, mas quando esta deixa de responder à particularidade cultural e não se reformula em resposta às condições sociais e culturais nas quais seu escopo de aplicação está incluída. Se, por razões sociais, não for possível se apropriar de um preceito universal ou se é preciso recusá-lo, este se torna um terreno de disputa, perdendo seu status de precondição para um debate democrático. Isso demonstra que há condições em que a universalidade pode exercer a violência ao demonstrar sua indiferença para com as condições sociais, levando a um sofrimento imposto, às custas da liberdade e da particularidade. Vale a pena ressaltar que todas as ideias da moral ou do comportamento ético deve se relacionar a um eu que age e que não está separado das condições sociais de seu surgimento, o que leva as normas a terem um caráter social que excede ao significado puramente pessoal. (49) 
Assim, o eu não é simples efeito ou instrumento de algum ethos prévio ou de algum campo de normas conflituosas, mas antes, ao relatar a si mesmo, por mais que comece a falar sobre si, descobrirá que está implicado em uma temporalidade social que excede sua capacidade de narração. Essa ideia leva à proposta de um fundamente subjetivo da ética, sendo a condição para a investigação moral ou para o próprio surgimento da moral. Caso o eu não esteja de acordo com as normas morais, isso significaria que o sujeito deve pensar e deliberar sobre essas normas, sendo que parte dessa deliberação levaria a uma compreensão crítica de sua gênese social. A divergência entre o universal e o individual torna-se a condição do questionamento moral e, mais além, é ela que leva o indivíduo a experimentar o que se torna a experiência inaugural da moral. (49)

Butler, dessa forma, se vê às voltas com o questionamento de se o eu que deve se apropriar das normas morais de uma maneira vital não seria condicionado por essas mesmas normas que estabelecem a viabilidade do sujeito. Para ela, uma coisa é dizer que o sujeito deve se apropriar das normas, que estariam fora do sujeito, e outra é dizer que que deve haver normas que preparam o sujeito dentro do campo ontológico. Portanto, mesmo que a moral forneça um conjunto de regras que produz um sujeito em sua inteligibilidade, ainda sim é um conjunto de normas e regras que o sujeito deve negociar de maneira reflexiva. Seguindo o pensamento de Nietzsche e de Freud, a autora conclui que a conduta humana que busca seguir normas de valor prescritivo seria muito mais motivada pelo medo de ser punida do que pelo desejo de fazer o bem. (49)

Essa questão do medo da punição remete ao pensamento de Hans Jonas, quando afirma que não saberíamos sobre a sacralidade da vida se não houvesse assassinatos e o mandamento "não matarás" não revelasse essa sacralidade. Na busca de uma ética da responsabilidade a longo prazo, é necessária uma ameaça à imagem humana para que surja, com o pavor gerado, uma imagem humana autêntica. Dessa forma, o medo pertenceria à responsabilidade assim como a esperança, mas não seria um medo que não nos faz agir, mas pelo contrário, o medo que nos convida a agir. A teoria ética necessita da representação do mal e do bem, sendo que o bem, que historicamente passou a ficar menos nítido, necessita da antevisão de novos males para que se ganhe nitidez. Para o autor, nessa situação, o medo e o mal trariam juntos o bem a ser defendido, tornando o medo a primeira obrigação preliminar de uma ética de responsabilidade histórica, sendo que, além disso, o medo deve estar sempre acompanhado da esperança, com o objetivo de se evitar o mal. (50) 
Ainda seguindo o pensamento de Butler, a norma não produziria o sujeito como seu efeito necessário e muito menos o sujeito seria totalmente livre para desprezar essa norma, o que leva o sujeito a lutar com condições de vida que não teria escolhido. Dessa forma, nessa luta, a capacidade de ação ou de liberdade do sujeito funciona dentro de um campo de restrições. Assim, a filósofa se pergunta se o fato de o sujeito não ser fundante de si mesmo não impossibilitaria a possibilidade de responsabilidade desse sujeito para com o outro. Ao se perguntar, ela já responde alegando que uma teoria da formação do sujeito, que reconhece a si mesmo como limitado de conhecimento sobre si, pode sim sustentar uma concepção ética de responsabilidade, pois momentos de desconhecimento sobre si mesmo tendem a surgir no contexto de relações com os outros. Esse espaço, dessa forma, seria o cenário da responsabilidade ética do sujeito. (49)

Dessa forma, existe uma dependência fundamental de nós com os outros, pois não podemos existir sem interpelar o outro e sem sermos interpelados por ele. É impossível fazer um relato de si mesmo fora dessa estrutura de interpelação, mesmo que o interpelado esteja implícito, anônimo, indefinido. Assim, pensar a responsabilidade não pode defini-la baseada em um conceito de si mesmo totalmente transparente para si mesmo, mas responsabiliza-se por si mesmo é reconhecer os limites de toda a compreensão de si e estabelecer esses limites não só como uma condição para o indivíduo, mas uma precondição para a comunidade humana: (49)

O relato que dou de mim mesma se desintegra, e certamente por uma razão, mas isso
não significa que eu possa dar todas as razões que fariam dele um relato completo.
Sou atravessada por razões que não consigo recuperar totalmente (...). Eu falo como
um "eu", mas não cometo o erro de pensar que sei exatamente tudo que estou
fazendo quando falo dessa maneira. Descubro que minha própria formação implica o
outro em mim, que minha estranheza para comigo mesma é, paradoxalmente, a fonte
de minha conexão ética com os outros. Preciso conhecer a mim mesma para poder
agir com responsabilidade nas relações sociais? Em certa medida, com certeza sim.
Mas há algum valor ético no meu desconhecimento? Se estou magoada, descubro
que a mágoa atesta o fato de que sou impressionável, entregue ao outro de maneiras
que não posso prever ou controlar totalmente. Não posso pensar na questão da
responsabilidade sozinha, isolada do outro. (2015, p. 112)

Portanto, se o "eu" não pode ser separado da vida social, então a ética não pode ficar apenas no campo da retórica, mas também da crítica social. Deve-se pensar a formação do sujeito para se entender a resposta ética e a teoria da responsabilidade. Algumas visões de investigação moral sobre o si mesmo acaba levando para narcisismo apoiado nos modos de 
individualismo socialmente impostos, levando, consequentemente, a uma violência ética que não conhece a aceitação de si ou do perdão. Portanto, torna-se urgente reformular a questão da responsabilidade para que possamos entender como somos formados na vida social e a que custo. A ética requer que nos arrisquemos exatamente nos momentos de desconhecimento e desfazimento em relação ao outro, pois sermos defeitos pelo outro é uma necessidade primária, que gera angústia, mas também oportunidades de sermos interpelados e impelidos a agir, abandonando o nosso "eu" autossuficiente. (49)

Hans Jonas coloca que a atuação dos humanos sobre objetos não humanos nunca havia sido um campo de domínio da ética, pois esta dizia respeito ao relacionamento direto do ser humano com o ser humano, revelando seu caráter antropocêntrico. Nos últimos anos essa esfera começou a migrar para o domínio do fazer coletivo, impondo à ética uma nova dimensão de responsabilidade, passando a importar o ator coletivo e o ato coletivo, não o ator individual e o ato individual. A horizonte de responsabilidade é fornecido muito mais pelo horizonte do futuro indeterminado do que pelo espaço contemporâneo da ação: (50)

\footnotetext{
Isso exige imperativos de outro tipo. Se a esfera do produzir invadiu o espaço do agir essencial, então a moralidade de invadir a esfera do produzir, da qual ela se mantinha afastada anteriormente, e deve fazê-lo na forma de política pública. Nunca antes a política pública teve lidar com questões de tal abrangência e que demandassem projeções temporais tão longas. De fato, a natureza modificada do agir humano altera a natureza fundamental da política. (2006, p. 44)
}

\section{Barebacking e autonomia}

Pensando a saúde nesse enfoque, como podemos mensurar a responsabilidade individual de uma pessoa que se sabendo soropositiva em relação ao HIV, faz sexo inseguro com o intuito de infectar um outro indivíduo? Em relação à responsabilidade pública, como o Estado pode melhor alocar seus recursos e o que priorizar ao se pensar em uma política pública? Segundo Hans Jonas, o homem público tem como objeto de responsabilidade a coisa pública e ao longo de seu mandato assume responsabilidade pela totalidade da vida da comunidade. Essa relação é de afeto por parte do indivíduo político, pois ele surgiu dessa 
coletividade e se tornou dentro dela, como uma identificação com o coletivo, de solidariedade. (50)

Para o contágio do HIV e para se pensar a autonomia de não se cuidar ou não se tratar, o barebacking visto a partir de um conceito de risco coloca em evidência o conceito de autonomia como uma decisão moral de responsabilidade perante uma doença e perante os outros, no caso do HIV.A questão seria de fácil resposta caso pensássemos que a pessoa decide não se tratar e ponto final ou decide se arriscar em um sexo sem preservativo. Quem quer se tratar, medicar-se-ia e a política continua seu rumo ao fazer seu papel medicando apenas quem deseja tomar os remédios.

O problema é que ao se pensar na política pública e no conceito de justiça social, no caso da saúde, é impossível não se pensar na transmissibilidade do HIV. Quem tem o HIV e não se medica, está com a carga viral alta e, assim, fica mais fácil de transmitir o HIV. Taylor (11) defende que cada pessoa tem o direito de organizar sua própria vida baseado no que ela ache importante ou valioso, o que seria, para o autor, um individualismo de auto-realização, que seria típico das sociedades ocidentais desde os anos sessenta. O problema é que esse individualismo implicaria uma intensa concentração no eu e uma exclusão de temas que vão para além do eu, que poderiam ser religiosos, políticos ou históricos.

Portanto, cabe aqui o papel fundamental da responsabilidade e, para isso, um imperativo adequado para essa nova ética deveria se deslocar do pensamento kantiano de que deveria se agir de modo que sua máxima se torne lei geral para o imperativo de que devemos agir de modo que os efeitos de nossas ações sejam compatíveis com a permanência de uma autêntica vida humana na terra, isto é, não pôr em perigo as condições necessárias para a conservação da humanidade no planeta. Assim, esse imperativo estaria muito mais voltado para a política pública do que para a conduta privada, o que gera uma responsabilidade baseada não mais na objetividade, mas na constituição subjetiva da autodeterminação humana. O novo imperativo clamaria não pelo ato consigo mesmo, mas para seus efeitos finais para a continuidade da vida humana no futuro. Assim, não seria uma universalização hipotética, isto é, transferir do "eu" individual para um "todos” imaginário, sem conexão causal, mas as ações do todo coletivo assumem a característica da universalidade na medida em que é realmente eficaz em relação a um futuro previsível e concreto. (50) 


\section{CAPÍTULO 3. RESULTADOS E DISCUSSÃO}

Em linhas gerais, o presente capítulo apresenta e discute os principais dados encontrados a partir da análise do software IRAMUTEQ e dos relatos obtidos pelas entrevistas. Voltamos a trazer o dendograma com os eixos referentes às falas degravadas das entrevistas para melhor compreensão dos resultados. A discussão foi organizada em torno de dois tópicos principais que orientaram a divisão dos capítulos anteriores, trabalhando as falas dos entrevistados em cima dessas questões, a saber, a política social e seu conceito de justiça; e a autonomia individual e a autonomia coletiva.

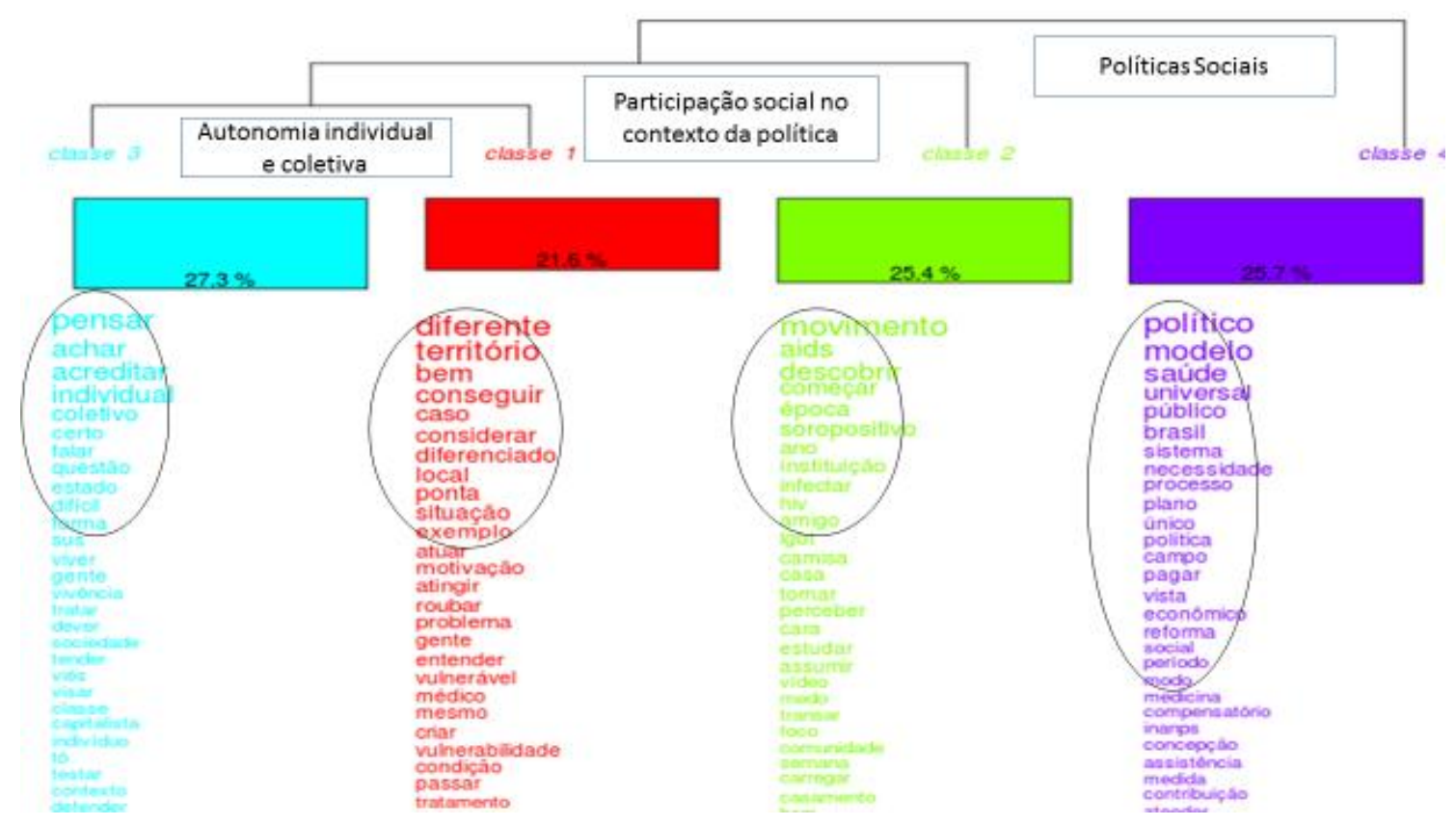

Figura 4 - Nuvem de acordo com o dendograma produzida pelo software IRAMUTEQ

Em relação aos dados desta pesquisa, foi buscado, a partir das elaborações dos informantes, identificar um campo de narrativas sobre os conceitos de justiça referente às políticas sociais do HIV e autonomia na escolha de querer ou não se tratar ou mesmo de ter um comportamento de risco, como o barebacking. A partir da análise dessas classes, emerge as dimensões referentes às suas vivências e percepções referentes aos temas propostos nessa dissertação. 


\section{A política social e seu conceito de justiça}

O corpus com os dados de todas as informantes revelou a existência de falas que foram remetidas a "político", "modelo", "saúde”, "universal”, "público", "sistema único", entre outras, conforme visto na classe 4 do dendograma. As falas que tiveram como relevantes palavras como "movimento", "aids", "descobrir", “começar", "época", "soropositivo", "território", "diferente", "local", "ponta", conforme classes 1 e 2, junto aos conceitos referentes à participação da população nas políticas sociais de saúde no contexto brasileiro e o conceito de justiça nas políticas sociais, também, foram trabalhadas. Essas classes foram pistas importantes para a organização dos relatos das informantes, conforme será mostrado.

A política social tem formas diversas nos países ocidentais e tem impacto direto no que a sociedade vai entender como cidadania. Uma remete-se à uma ideologia mais liberal e tem cobertura focalizada; outra de ideologia corporativa, normalmente ligada a algum grupo ocupacional; e a última seria de ideologia social-democrata e se baseia no princípio da justiça e de cobertura universal (22). O Brasil tem como princípio este último modelo, o que determinou uma busca de promoção de justiça social baseada na busca de melhorias sociais para alguns segmentos populacionais, equilibrando a distribuição e a organização de serviços de acordo com as necessidades específicas desses grupos sociais (28). O entrevistado Haroldo traz os seguintes questionamentos sobre justiça e que serão interessantes para se pensar o conceito mais alargado de justiça:

"Haroldo: Hoje você tem, pelo menos do ponto de vista do direito, de assegurar o seu direito à saúde, você tem assegurado isso... agora como isso se conforma em acesso, acessibilidade, distribuição dos benefícios que estão à disposição, então isso é uma outra questão...

Eu: Então, por exemplo, no HIV, tem as populações que não são acessadas...

Haroldo: Sim, mas todas elas têm acesso a medicamento, independentemente de qual seja a sua condição, todas elas têm acesso ao medicamento, então o acesso ao medicamento é universal... o que você encontra são barreiras assistenciais na conformação de uma rede de atenção [...] Já é um passo enorme do ponto de vista do direito à saúde [...] Por que que uns são diferentes dos outros? Essa é a pergunta básica da justiça. Como é que se diferencia uma de outra pessoa por causa do adoecimento. Por que uma pessoa é mais que outra em relação ao adoecimento? [...]Então, eu não acho que exista essa noção de justiça que separa os indivíduos. A partir de uma... eu sou diferente de outra pessoa, porque eu disponho dos meios que me assegure a viver, por que que o outro não dispõe dos mesmos meios para assegurar a viver... aí não há dúvida que tem que ter intervenção do Estado... então o Estado tem que intervir justamente para evitar essa brutal desigualdade em relação a essa questão de valores e quando você atribui à saúde um valor, não é? Que não é o valor monetário, é um valor de outra natureza, que tem outro significado, que tá relacionado à vida da pessoa, à dignidade da pessoa, que a minha dignidade e minha vida é muito igual à sua, entendeu?" 
Portanto, o que podemos ver é que a justiça que é feita está no nível de acesso ao tratamento, isto é, de distribuição de medicação para todas as pessoas que estão infectadas. A questão que se coloca é que os indivíduos são diferentes e que o Estado seria responsável pela intervenção no contrabalanceamento dessas diferenças para uma busca de igualdade. Garrafa (19), por exemplo, aponta a necessidade de a bioética tomar posição para a inclusão social, voltando-se para o alcance da verdadeira justiça social, o que faz pensar que a justiça social vai para além da distribuição de medicação, mas inclui esses segmentos que estão à margem da sociedade.

Pensando desde a nossa redemocratização, os anos 1980 tiveram como grande marco para saúde o surgimento dos conselhos municipais como espaços de participação e de controle social pelos usuários do sistema de saúde, o que engendrou a criação do Sistema Único de Saúde. Em 1990 há, por meio da lei 8.142, a regulamentação da participação social no sistema de saúde, o que já demonstrou um movimento para a inclusão social, mas de uma forma mais ampla, sem pensar a segmentação por população, mas focando nos usuários da saúde (26). A questão é que esta lei não teve desdobramento, o que deixou em aberto a forma que seria feito o controle social, afetando diretamente o movimento referentes ao HIV/aids. Podemos ver pela fala de Iara, que há mais de 20 anos trabalha no SUS, e que considera que por mais que esses espaços tenham sido construídos ao longo da Reforma Sanitária, eles ainda não estão consolidados, conforme discurso abaixo:

\footnotetext{
“[...] Agora eu acho que o maior equívoco que existe é, nessa questão da aids, é como que essa sociedade civil se enxerga, porque eu lembro, várias vezes eles vinham a mim e falavam assim: Iara, tem algum lugar que está escrito que se a gente participar do conselho, a gente está sendo prestador de serviços? Falei não, não existe nenhum lugar, porque o SUS só foi até a 8080, ela foi agora pelo decreto 7508, que ela foi regulamentada. A 1142 não foi nunca. Então, quando você faz uma lei que você envolve a comunidade, a primeira coisa que você tem que fazer é regulamentar o papel dessas comunidades, dessas organizações: elas podem isso, não podem isso, podem até daqui a pouco, não podem mais, você tem que regulamentar isso. Eles estão totalmente perdidos. Aliás, eu mesma, se for ver, hoje, não há regulamentação da 1142. Ela é uma lei que fala da conferência, fala da criação dos conselhos, que fala da participação comunitária e não fez nenhuma regulamentação sobre iss. [...] Então o controle social para mim não está regulamentado, então temos muito que trabalhar. Eu acho que tem algumas coisas que podem já estar ganhas por prática, mas eu não concordo que ele esteja claro."
} 
Percebemos, dessa forma, que se existem pessoas que historicamente não estão inseridas socialmente, elas estão em situações de vulnerabilidade social. Apesar da Constituição Federal de 1988 inovar ao trazer o conceito de inclusão social e de que houveram desdobramentos no sentido da participação social, acabou que as políticas sociais foram focalizando-se para as situações de pobreza. Para Theodoro e Delgado (24), as populações em contexto de vulnerabilidade social devem ter garantia dos direitos sociais básicos estruturados no aparelho do estado, que seriam exercitados por iniciativa do cidadão, como direitos permanentes, independentes de governo e protegidas de cortes orçamentários. Dessa forma, cabe lembrar que os planos plurianuais dos últimos anos tendem a retirar o enfoque na pobreza e destacar os temas transversais, que seriam as populações vulneráveis, criando agendas referentes às desigualdades raciais, mulheres, população LGBT, entre outras. Isso pode ser visto na fala de Aílton e na sua experiência no âmbito federal:

"[...] Por exemplo, quando a gente fala que a população chave [...], como tem a política de saúde integral da população LGBT, que vai direcionando e assim a gente vai fazendo direcionamentos também, como a gente tá prevendo fazer ano que vem, desenhar uma política nacional de saúde, prevenção e tratamento do HIV para a juventude, pra ficar cada vez mais específico, porque a gente entende que todos os cidadãos têm direito à saúde, isso está garantido, mas a gente entende também que tem populações que são mais vulneráveis, que são atingidas de maneira mais desproporcional, então assim, a política social é uma coisa bem ampla..."

No âmbito do Ministério da Saúde foi criado o DAGEP (Departamento de Apoio à Gestão Participativa) que para além do apoio e incentivo para o fortalecimento do controle social, começou a trabalhar com os temas dessas populações mais vulneráveis (27). A questão que se coloca é de que não se pode pensar nessas populações como ações transversais a serem trabalhadas pelo governo central, sem levar em consideração o território, pois o município é quem acaba tendo papel fundamental na articulação entre sociedade civil e as instâncias governamentais. Para Aílton, apesar do nível central pensar a política social em seu caráter amplo, este acaba trabalhando no nível territorial ao se pensar a política para as populações em maior contexto de vulnerabilidade social:

“[...], porque assim, os departamentos, pelo menos no Ministério da Saúde, que é o que eu tenho referência, os departamentos eles têm esse papel de tentar ver as questões de território, apesar de ele não atuar nos territórios, [...]. Por exemplo, quando você faz ações individuais, como o DAGEP, por exemplo, que faz ações para a população LGBT, eles consideram as vulnerabilidades dessas populações $e$ de outras populações que eles trabalham, né. Então, na verdade, o Ministério da Saúde como um todo, se a gente pensar lá no ministro, talvez ele tenha uma visão 
mais global, mas o papel dos departamentos é justamente esse, de também considerar os territórios, as questões individuais".

Para Garrafa e Porto (20), a igualdade seria o ponto de chegada da justiça social. Trabalhando com a inclusão social das populações consideradas vulneráveis, a proposta é que se chegasse à igualdade. Inicialmente como forma de equidade, já que as ações das políticas sociais se voltaria para a busca de se incluir qualquer população que estivesse à margem, com o intuito de alcance da igualdade. O entrevistado Aílton considera justiça a própria equidade, já que ele considera que as pessoas não seriam iguais e problematiza a questão de se pensar todo mundo como igual, já que mesmo os espaços de sociabilidade diferenciam as pessoas.

“Aílton: A justiça pra mim é equidade. Eu acho que nem todo mundo é igual, nem
todo mundo é igual. Eu acho que tem muita diferença, usando a mesma população,
mas existe muita diferença entre uma profissional do sexo aqui do Distrito Federal
e uma profissional do sexo lá do interior do Ceará. Porque a condição de trabalho
delas pode ser extremamente diferente. Eu falo isso porque, por exemplo, eu tenho
uma amiga no Rio Grande do Sul que é prostituta e fala disso com muita
naturalidade, foda, a menina é novinha, mas manda muito bem. E ela fala pra mim
que um programa dela custa entre 300 e 400 reais. Ela trabalha numa casa
fechada, onde tem outras 60 garotas e elas trabalham com segurança, entendeu? É
uma situação completamente diferente de uma profissional do sexo que tá lá na
estrada, no interior do Ceará. Então, assim, como é que eu não olho diferente pra
essas duas pessoas? Mesmo que elas façam a mesma coisa, né? Mas a
vulnerabilidade dessa menina que tá no interior do Ceará é muito maior. Então,
assim, essa garota do Rio Grande do Sul, de Porto Alegre, ela tem condições, ela
tem discernimento de procurar uma unidade de saúde, às vezes até de pagar um
plano de saúde pra ela."

Portanto, percebe-se uma dificuldade nos conceitos de igualdade e equidade. De acordo com Kerstenetzky (29), o marco em termo de justiça, isto é, o conceito que uma determinada sociedade utiliza do que é justiça torna-se crucial para esclarecer nossas atitudes perante estilos de política social. Na equidade, a ideia não é simplesmente privilegiar os desfavorecidos, ainda que isso seja necessário, mas arranjar a sociedade e suas instituições para que os cidadãos possam conduzir seus assuntos com apropriada igualdade social e econômica. Dessa forma, a questão passa a ser anterior, de como a sociedade daquele lugar entende o que é justiça social. Iara problematiza o que é justiça ao se remeter às suas experiências de trabalho:

“O conceito de justiça tem que estar super bem escrito, mas eu não me preocupo com isso, porque eu me preocupo com a aplicação do conceito. Então, a aplicação do conceito para mim é totalmente equivocada porque não são todos iguais perante a lei, não são. Então você tem as diferenças, de cor, de raça, de nível social, então eu vejo assim, eu sou muito radical nesse ponto, pra mim esse país é uma grande balela." 
Pensando a repolitização dos conflitos morais focando nas populações que estão em situação de maior vulnerabilidade social, conceito muito caro à Bioética de Intervenção, Alana traz uma discussão interessante ao falar das diferenças e da equidade:

“[...] O tripé do SUS é a universalidade, a integralidade e a equidade e desses três o
que sempre me pautou, que é um princípio do SUS que pra mim é um princípio de
vida é equidade. Eu não sou igual a você. Ambas somos mulheres e ponto final. A
justiça nos reconhece assim, nós nos reconhecemos assim e as pessoas do nosso
meio. Nós temos uma diferença, quer dizer, eu estou partindo do pressuposto que
você tem um útero, certo? Eu não tenho útero. Na hora que você por exemplo
precise de um atendimento, quer dizer, nós duas somos mulheres, mas você vai
precisar de um ginecologista, por exemplo, agora, de um obstetra se você ficar
grávida. Eu, por exemplo, se eu não fiz a minha cirurgia ainda, eu preciso de um
proctologista, de um urologista pra analisar minha próstata. Então, assim, nós
somos iguais, no sentido de reconhecimento, mas nós temos as nossas
especificidades. Se nós formos tratadas como iguais, a gente não vai ter saúde
promovida, porque eu não preciso de um ginecologista agora, entendeu? Então pra
mim é o conceito da equidade, que vai já desde eu reconhecer essas diferenças,
mesmo a gente tendo essa igualdade do ser mulher, como por exemplo eu sou uma
trans, [...]Pra mim a universalidade ela está totalmente atrelada à equidade. Pra
mim elas são uma coisa só, não é nem braço dado, elas são coladas, pra mim.
Porque universalidade é isso, você atender todo mundo, atender a todas as
questôes, mas como atender todo mundo se eu vejo todo mundo como uma massa
só? [...]"

É interessante perceber que a entrevistada atrela à equidade á universalidade, a partir de sua experiência vivida como mulher transexual. Ao me comparar a ela, coloca claro que no âmbito de questão de gênero, fazemos parte do gênero feminino e, além disso, temos os mesmos direitos de cuidado da saúde. Quando se entra na questão da individualidade, esta perpassa por especificidades para que essa mesma saúde seja promovida igualmente para nós duas, isto é, nossas diferenças têm que ser respeitadas para sermos atendidas da mesma forma.

O ponto importante é que o Estado acaba vendo todas as pessoas como uma massa, já que ao se pensar na política social para todos, de acordo com Fortes e Zoboli (8), a saúde tenta assegurar condições para que as pessoas sejam saudáveis, não se dando conta que essas ações podem gerar conflitos morais, pois podem vir a limitar ou restringir liberdades e decisões individuais e, além de tudo, baseiam-se na noção ética utilitarista do maior benefício para a maior quantidade de pessoas, controlando estilos e comportamentos de vida que são considerados não-saudáveis, preconizando o que seria uma vida perfeita. 


\section{A autonomia individual e a autonomia coletiva}

Autonomia individual e autonomia coletiva passam pelos conceitos de Garrafa e Porto (20), nos quais a ação social politicamente comprometida é a única que poderia transformar a práxis social, enfatizando a identidade pública adquirida pela ética em contraponto à esfera individualista. A grande questão em relação ao conceito de autonomia é este nos levar a um egoísmo exacerbado, anulando as visões coletivas que seriam indispensáveis para se pensar a questão da justiça social e a busca da igualdade. Para o entrevistado Haroldo, a autonomia é uma questão de decisão individual, mais ligada ao conceito kantiano, na qual o sujeito decide por si o que fazer ou não em uma determinada situação, sendo que não cabe ao Estado qualquer tipo de interferência nessa autonomia individual:

\footnotetext{
“Mas qual é o papel do Estado? Qual o papel do Estado? O papel do Estado é, se o indivíduo toma a decisão de não querer se tratar, isso é um direito do indivíduo, mas o Estado não pode se omitir de contemplar ou de oferecer e de garantir, caso ele tome a decisão de querer se tratar, que tenha à disposição dele os meios necessários para ele poder se tratar. Então o que o Estado tem que fazer é garantir os meios, o Estado tem o papel de garantir os meios, mas o Estado não pode agir sobre o indivíduo de modo a quebrar a autonomia de sua decisão..."
}

De acordo com Bourdieu (33), a questão central parece voltar-se para processos de autonomia, que não se confundiria com o individualismo alheio ao social, nem com a alienação de sujeitos em função de seu grupo, mas uma autonomia que impulsiona o Estado a revisitar valores, competências e processos específicos que se afirmam enquanto portadores de demandas diferenciadas, relacionadas aos diversos grupos. Isto iria de encontro com o que foi falado acima pelo entrevistado. Já para Sancho (36), a autonomia seria a capacidade de sermos responsáveis por nossos próprios comportamentos e de conduzir a nossa própria vida, de acordo com nossa própria consciência, o que equivaleria à liberdade.

Vale a pena, portanto, pensarmos se uma forma de se pensar participante de um coletivo nos faz entender melhor a autonomia individual e até mesmo pensá-la mais em termos de coletividade do que nos termos kantianos de individualidade. De acordo com Santos (37), as identidades coletivas passaram a ser compreendidas a partir não só de um agregado de interações sociais, mas também da razão político-estratégica de atores sociais que fazem parte desses espaços. Para Aílton e Alana não é bem o ativismo ou a militância que fazem essas pessoas tomarem decisões em nome do coletivo, mas a informação tem uma força muito 
grande nas tomadas de decisão referentes a buscar tratamento quando se descobre infectado ou o fato de se tomar uma decisão de não infectar o outro em uma relação sexual:

\begin{abstract}
"Aílton: [...] eu acho que o ativismo não faz da pessoa uma pessoa mais consciente não, eu acho que o que faz a pessoa mais consciente é a informação mesmo. As pessoas que tem mais informação, elas têm mais cuidado, então, assim, eu posso ser um cidadão sem nenhum tipo de publicidade na minha soropositividade e posso ter tanta informação que eu jamais vou transar com alguém sem camisinha, jamais, independente do que você fizer, sou super empoderado, e eu não vou fazer isso porque eu não quero correr o risco de te infectar e você tem que passar pela mesma coisa que eu passo, ou eu quero te infectar e carregar o peso de ter te infectado. $[\ldots] "$
\end{abstract}

\begin{abstract}
“Alana: [...] eu tenho muito mais acesso à informação, muito mais clareza, eu sei que represento várias pessoas, que eu sou um ícone pra várias pessoas, mas eu sou um ser humano, eu sou um ser humano em separado. Volto naquela mesma questão, uma travesti exatamente como eu te descrevi a pouco, pode ser uma líder de uma grande ONG, da maior ONG do Brasil, mas a vida dela particular tá estragada, tá um lixo, ela luta pelos outros, mas talvez a vida dela não tá legal e ela não quer mais aquilo. Então, facilita pelo acesso à informação, a informação é muito mais pronta, mas aí tem uma questão chamada decisão, a decisão não significa que eu tenho HIV, que eu vou querer me tratar. Vão ter as que querem, que vão dar o exemplo, que querem viver, que enfim, como pode ter aquelas que não queiram. Então, assim, a gente pensa muito no coletivo, e a gente acaba esquecendo o individual e é até o que eu brinco da militância, a militância pode ser maravilhosa, mas ela tira um pouco da sua humanidade. [...]"
\end{abstract}

Para Anderson, a questão vai além da informação, passa pela ideia da conscientização como cidadão, o que leva a pessoa a buscar por lutas sociais. A ideia de Cortina (44) coadunase com o fato de que as pessoas se fazem humana através de outras pessoas, desprendendo-se uma visão comunitária que assenta a comunidade como base do ser, do existir e da realização de todos os seres humanos:

\footnotetext{
“Anderson: [...] mas ainda tem pessoas que, até pela falta de informação, pela falta de acesso às informações, elas entendem que ainda pode ser uma sentença de morte, embora isso tenha mudado. A partir do momento que você começa... eu me lembro, a primeira vez que eu cheguei na instituição, eu imaginei, já contei essa história mil vezes, eu imaginava encontrar - isso foi no ano de 1995, fazem 20 anos agora - eu imaginava chegar na instituição e encontrar pessoas desfiguradas, pessoas cambaleando, pessoas com cara de morte, e eu cheguei num ambiente onde tava todo mundo feliz, todo mundo dançando, obviamente você via um ou outro que você percebia que tinha uma fragilidade maior. Então aquilo ali pra mim foi o que me marcou, né, e durante todo aquele tempo que eu vivi ali, eu vi pessoas que se isolaram e que rapidamente elas faleceram, porque elas deixaram de acreditar $e$ elas não aderiram ao tratamento, não quiseram viver em grupo, mas a maioria, eu acho super importante, porque você vai se conscientizando, a partir do teu individual, e passa a receber uma consciência coletiva, que você, enquanto cidadão,
} 
você tem direitos e deveres, e um dos deveres é você lutar por respostas individuais e coletivas, né, então eu vejo como um grande passo pra você entender a necessidade de se estar em grupo pra se fortalecer individualmente e coletivamente. [...] Na medida em que você passa a ter essa consciência que, enquanto cidadão, eu tenho direitos e deveres, você também passa a deixar de olhar pro próprio umbigo e lutar pelo coletivo. E aí quando você fortalece coletivamente, você tem mais argumentos pra reivindicar políticas públicas, [...] você passa a ter essa consciência do teu papel no mundo, do teu papel na sociedade, e o quanto você pode colaborar pra que você tenha respostas efetivas pro coletivo."

Aldo, ao pensar sobre o individual e o coletivo, coloca os seguintes pontos:

“Aldo: A questão de você não ligar apenas pro coletivo, porque eu acho que a questão do testar e tratar, talvez o principal intuito dela é pensar na questão da saúde coletiva, é pensar na redução da transmissão, é pensar nisso, eu acho que primeiro lugar, mas a gente não pode esquecer do nível individual que o nível da autonomia do indivíduo, de enfim, se tratar ou não. Eu acho que esse nível, ele nunca pode ser ignorado, sabe, e eu respeito muito quando vem os militantes e as próprias pessoas vivendo com HIV e batem nessa questão do individual, assim né, porque se saúde, se o ministério da saúde for pensar em todos, a gente justamente tem que pensar em quem vive também e a gente tem que pensar na autonomia do sujeito, né, no direito de autonomia do sujeito, mas é como eu disse, a partir do momento que eu comecei a ver essas pesquisas, que trazem o benefício pro lado individual também, eu comecei a achar firmeza nessa questão do testar e tratar, mas assim tendo essa base científica do benefício pro indivíduo. Eu acho que se não tivesse isso, eu estaria muito inseguro de falar de uma política de testar e tratar, por exemplo, se não tivesse essa coisa científica do benefício pro indivíduo, eu taria sendo contra, provavelmente. Eu seria um dos que ia falar, tá beleza, tá pensando na sociedade, mas na pessoa que vive com HIV você não tá pensando, né."

A fala do informante remete-se também à Cortina (45) em seu conceito de democracia radical, na qual há o respeito à diversidade das facetas humanas e das esferas sociais, e os seres humanos seriam vistos como interlocutores válidos, devendo ser tomados em conta dialogicamente. Portanto, isso demonstra que a visão moral única deve ser mudada para um pluralismo ético, de respeito às decisões dos outros, mas que não tiraria o Estado de seu lugar de produtor de política social, mas empoderaria os cidadãos para que participassem e decidissem de forma realmente coletiva.

Em relação ao aspecto da responsabilidade, Butler (49) coloca que a ideia da universalidade pode ser violenta pelo fato mesmo de se pretender universal. O surgimento de questionamentos morais leva a divergências entre o interesse individual e o interesse universal, onde o universal deixa de concordar com o individual ou de inclui-lo, fazendo com que a própria pretensão de universalidade ignore os direitos dos indivíduos. Para a autora, o problema não é a universalidade em si como violenta por definição, mas quando esta deixa de responder à particularidade cultural e não se reformula em resposta às condições sociais e 
culturais nas quais seu escopo de aplicação está incluída. De acordo com Garrafa (20), a ética começa a ter maior importância aplicada à análise das responsabilidades sociais, sanitárias e ambientais, além das formas de intervenção pública em relação à responsabilidade frente aos cidadãos. Haroldo deixa muito claro em sua fala a importância da responsabilidade quando se pensa a autonomia:

\begin{abstract}
"Entendeu? Agora, a defesa da autonomia, ela deve ser pautada uma outra dimensão ética. A autonomia tem que ser pautada pela questão da responsabilidade, você tá entendendo? Quer dizer, a minha autonomia, é óbvio que eu vou lutar pela minha autonomia, vou lutar pela sua autonomia, vou lutar pela autonomia coletiva, né? Pelo princípio da autonomia pelo princípio da afirmação do sujeito, do ser... se eu faço isso, eu tenho que olhar para forma de modo a ver que ponto minha autonomia não fere a autonomia do outro, que é a responsabilidade... em que momento a minha autonomia não vai ferir a autonomia do outro. [...] “
\end{abstract}

Portanto, para Butler (49), torna-se urgente reformular a questão da responsabilidade para que possamos entender como somos formados na vida social e a que custo. A ética requer que nos arrisquemos em relação ao outro, o que traria a ideia da alteridade e também de dependência fundamental de nós em relação ao outro. A responsabilidade, dessa forma, é o fato de reconhecer que você é limitado em sua autossuficiência e em sua compreensão de si, pois a formação do indivíduo passa pelo o outro em mim: a responsabilidade é a alteridade.

É interessante pensar esses conceitos quando se remete ao comportamento como o barebacking. Este é um ponto em que se mede ou pensa o que seria a responsabilidade individual ou coletiva. Para Hans Jonas (50), por exemplo, nossos atos deveriam se basear no fato de que os efeitos de nossas ações sejam compatíveis com uma vida considerada autêntica, pensando sempre na perpetuação da vida humana no futuro.

De acordo com Anderson, ao se pensar o bareback e possibilidade de infectar o outro pelo HIV:

“[...] Acho que tem desejos, né, individuais, que pertencem a cada um, e isso são questões muito difíceis de você mudar, né, acho que são os desejos, são as vontades de experimentar coisas diferentes, agora, o papel nosso, enquanto formuladores de opinião, enquanto promotores de ações pro coletivo, nosso papel é levar informação, né, mas a gente não pode obrigar as pessoas a tomarem decisão, né, então, o nosso código penal ele deixa claro quando você, intencionalmente, tem essa atitude, digamos, de transmitir o vírus HIV, agora também quem participa desses atos, é uma relação consentida, então é aquela coisa, a prevenção é para todos, não é só pra quem tem o HIV, o cuidado que a gente tem que ter é de não criminalizar as pessoas, lembrando que o outro também tem responsabilidade, uma relação a dois se dá a partir da vontade dos dois, salvo no caso de violência, que existe, mas numa festa dessa todo mundo tá consciente, então não dá pra responsabilizar apenas a pessoa vivendo com HIV/aids, a consciência $e$ a 
precaução, ela serve para todos, né [...] mas sem deixar de lembrar que o outro também tem responsabilidade."

Para Iara, a questão passa por valores e educação, o que podemos ver que os preceitos morais de uma sociedade ou de um grupo social são a base para que se eduque buscando a se pensar no coletivo. Para ela, o Estado é fundamental nesse processo:

\begin{abstract}
"Olha, isso é muito difícil de discutir, porque nós temos uma questão de valores, valores sociais, valore psicológicos, valores familiares, e nós crescemos assim, né? Se não houver uma motivação, se não houver quase que uma educação ideológica, você não vai conseguir com que eu faça uma coisa que eu não quero fazer. Eu posso até dizer que faço, e não fazer, né? Então eu acho que está faltando uma ideologia para essas coisas, sabe?"
\end{abstract}

Segundo Hans Jonas (50), o homem público é fundamental em sua responsabilidade com a coisa pública e pela vida das comunidades para as quais trabalha. Para o autor, isto passa pelo nível do afeto, identificando-se e solidarizando-se com o coletivo. O problema é que ao se pensar na política pública e no conceito de justiça social, no caso da saúde, é impossível não se pensar na transmissibilidade do HIV.

Taylor (11) defende que cada pessoa tem o direito de organizar sua própria vida baseado no que ela ache importante ou valioso, o problema é que isso gera o individualismo que implicaria uma intensa concentração no eu e uma exclusão de temas que vão para além do eu. Para o autor, barebacking não pode ser visto como um conceito, mas como uma atitude tomada tanto em contextos morais como sociais. O barebacking pode ser visto tanto como um desafio em relação a uma responsabilidade coletiva quanto como uma complexa evolução na percepção de homens gays sobre pertencimento a uma determinada comunidade.

Para Taylor (11), questões individuais e coletivas estão interconectadas, pois ao reconhecer a diversidade de formas de prevenção, necessariamente estaria criando-se mais inclusão da comunidade nessas questões. Se as questões de prevenção forem tomadas em âmbito individual ou coletiva, o risco de se fazer sexo sem preservativo ou a recusa ao tratamento deve ser considerada dentro dos conceitos de responsabilidade individual ou coletiva. Aílton ilumina essa questão ao falar de sua experiência: 
camisinha, eles assumem um compromisso, na verdade existe uma relação de compromisso um com o outro, mesmo que eu nunca tenha te visto, eu assumo um compromisso de que eu estando infectado ou não ou você estando infectado ou não, a gente vai transar sem camisinha porque a gente quer. É mais como uma cultura mesmo, eu entendo isso. Agora a transmissão intencional do HIV, quando aquela pessoa pira, e tipo ai eu vou passar pra todo mundo, eu conheço não as pessoas, mas várias pessoas que foram infectadas por esse tipo de pessoa, nesse caso é uma pessoa que simplesmente tem má índole mesmo, como a pessoa que resolve matar pra comer ou uma pessoa que resolve roubar pra satisfazer um ego de ter um relógio mais caro. Então eu acho que são duas situações bem diferentes. Pra mim são crimes, mas com motivações diferentes. Um motivo é torpe e outro motivo tem alguma relação física, o que me leva àquilo é que eu preciso comer, eu preciso tomar banho, saindo da questão física, mas eu preciso pra viver bem, eu preciso tomar banho, pagar a minha energia, então eu preciso roubar. É uma motivação. $O$ outro é aquela motivação, ah tipo eu quero ir pra balada e quero exibir um celular caro[...] O medo de você descobrir é muito maior do que meu medo de infectar, o que é um pouco de egoísmo também, entendeu, isso acontece. Agora aquelas pessoas que tipo ah eu vou sair fudendo todo mundo, vou sair transando, porque aí é engraçado porque geralmente essas pessoas elas sabem como fazer isso, porque eu sei que eu ativo numa relação gay, eu tenho maior possibilidade de transmitir pra outro cara, então eu não vou dar pra ninguém, seu eu quero transmitir, eu vou ser ativo, vou gozar dentro do cara, eu vou deixar lá dentro um tempo, eu vou tentar fazer um sexo mais violento pra machucar ele mais, pra poder tentar conseguir atingir o meu objetivo, é gente maldosa né." 


\section{CONSIDERAÇÕES FINAIS}

A pesquisa permitiu compreender diversos aspectos referentes tanto à teoria referente à justiça e outros conceitos ligados às políticas sociais quanto à teoria referentes às autonomias coletivas e individuais, sempre buscando compreender a importância e o papel da bioética ligada a essas questões.

Muitos desafios existem ao se pensar a universalidade, equidade e igualdade dentro das políticas sociais. Vale relembrar a importância que teve e que ainda tem as lutas e conquistas de liberdades individuais e também ao reconhecimento dos direitos de mulheres, homossexuais e negros, entre outros grupos políticos e de que os movimentos sociais ligados ao HIV/aids surgem exatamente nesse período efervescente, atuando no campo da saúde e da prevenção, além do combate as discriminações aos grupos, principalmente de gays, que foram mais afetados no período de início da epidemia.

A mudança de paradigma de tratamento para o HIV surgiu no ano de 2013 ao se preconizar tratamento para todos, independentemente da carga viral. Isso gerou incômodo em certa parte de militância que criticou a proposta de tratamento como prevenção como uma forma de se esquecer da prevenção clássica, isto é, do uso de preservativo, por exemplo, para se focalizar na medicamentação.

A proposta inicial da pesquisa era trabalhar com dois grupos: as pessoas que estão na gestão, pensando e formulando ações para as populações de jovens gays, transexuais e travestis que mais se infectam atualmente, na qual seria trabalhado o conceito de justiça em relação à política social do HIV e a percepção dessas pessoas sobre o tema; e um grupo jovem, que seria feito um grupo focal para se discutir barebacking para se gerar material para se pensar autonomia individual e coletiva.

No decorrer da pesquisa, foram realizadas as entrevistas e também foi realizado o grupo focal. Já com as falas do grupo focal degravadas, dois participantes me pediram para não participar mais do trabalho, o que fez com que eu ficasse apenas com as falas das pessoas que trabalham no Ministério da Saúde. Isso dificultou a pesquisa no sentido de que tivemos acesso apenas a uma parte do conteúdo que deveria ser trabalhado, pois os jovens gays que participaram do grupo focal trouxeram material importante sobre autonomia e responsabilidade.

Foi necessário, dessa forma, mudar o foco apenas para as pessoas que trabalham na gestão e alargar as perguntas para além dos conceitos mais amplos da política social, 
agregando as questões referentes à autonomia. O interessante é que dentro desse grupo entrevistado, temos 3 pessoas jovens (dois gays - Aílton e Aldo - e uma trans - Alana) e um dos coordenadores da área de prevenção e articulação social, Aderson, sendo que dois desses são HIV positivos (Anderson e Aílton), todos vindo da militância, enriquecendo a fala em relação à autonomia por meio de suas experiências pessoais.

Percebeu-se, portanto, que na fala das 4 pessoas que vieram da militância, a importância da responsabilidade de não infecção do outro pelo HIV faz parte de suas histórias de vida e não da teoria. É importante lembrar que nos últimos anos houve uma possibilidade de pessoas que vieram diretamente da militância pudessem atuar dentro do governo, buscando trazer a visão de pessoas que vivem na ponta a experiência. Claro que não podemos negar que isso pode trazer distorções ao se pensar que o governo ou o Estado é o espaço de militância, o que pode gerar confusões ao se utilizar o Estado como espaço de se fazer política partidária ou de busca de notoriedade pessoal nos meios políticos de onde essas pessoas vieram.

É importante pensar a intersetorialidade e a transversalidade, por meio do instrumento dos planos plurianuais, como tendências bastante atuais na gestão de políticas sociais, especialmente para governos locais, muito por conta da descentralização apregoada pela Constituição Federal, buscando garantir a qualidade de vida não somente nas políticas públicas, mas também nas relações que estas políticas estabelecem entre si no objetivo de atender às necessidades da população de um determinado território.

Já em relação às entrevistas das outras duas pessoas, Haroldo e Iara, a experiência em relação ao HIV sempre esteve relacionada ao âmbito federal, mas com larga experiência em relação ao controle social e Às populações em contextos de vulnerabilidade ao HIV. Percebese que eles têm forte pensamento mais generalizado e teórico, o que não tira o mérito de suas falas, pois a experiência exemplifica suas generalizações. Isto vem do fato de trabalharem no nível mais macro de construção de políticas públicas, o que também enriqueceu o trabalho.

Em relação à dificuldade percebida ao longo da escrita da dissertação é que os conceitos bioéticos são bastante teóricos se tomados como ponto de partida da pesquisa. A dificuldade deste trabalho foi no sentido de ter ficado mais fácil escrever a teoria e posteriormente ter utilizado o empirismo das falas dos entrevistados como forma de exemplificar a teoria, o que gerou confusão.

O processo de escrita sobre política social foi mais fácil, pois é um conceito mais palpável e de vivência diária, pois está ligada ao trabalho de qualquer pessoa que esteja no Executivo Federal. É uma vivência e lida diária, o que facilita a escrita sobre o tema. Em relação à autonomia, a questão já vai ficando mais difícil, pois o embasamento da bioética se 
dá muito por filósofos, o que deixa o tema menos palpável. Nesse momento a dificuldade foi maior, mas quando o conceito de responsabilidade foi tratado facilitou o pensamento sobre autonomia.

Um ponto importante que surgiu da dissertação foi que alguns entrevistados compraram equidade com igualdade e universalidade, muitas vezes como termos sinônimos. Creio que é de importância fundamental se pensar o que os diferencia e como a política social pode utilizá-los de forma que alcancemos uma ideal de saúde para todos. O mesmo se percebe em relação ao conceito de justiça, pois parece que no Brasil ainda não fica claro que tipo de justiça social trabalhamos, o que dificulta para o país utilizar ou o modelo mais focalizado ou o modelo mais universal, apesar de preconizado pela $\mathrm{CF} / 88$ o modelo universal. Isto também foi percebido na fala de alguns entrevistados, principalmente os que já trabalham na gestão há mais de 20 anos.

Vale lembrar que a Bioética quando escrita e pensada por autores latino-americanos ainda tem muito que andar e ganhar espaço como um instrumento de se pensar a ética aplicada, alargando o conceito de bioética baseado no principalismo, que como afirmam Garrafa e Azambuja (18), a epistemologia da bioética deveria se estruturar para além da forma pluralista, fundamental para a convivência pacífica, mas para questões multi/inter/trans disciplinar, com variados núcleos de conhecimento e de complexidade, para início de uma discussão responsável da contradição existente entre o universalismo ético e o relativismo ético. 


\section{REFERÊNCIAS BIBLIOGRÁFICAS}

1) Grangeiro A, Laurindo da Silva L, Teixeira PR. Resposta à aids no Brasil: contribuições dos movimentos sociais e da reforma sanitária. Revista Panamericana de Salud Publica. 2009; 26(1): 87-94.

2) Protocolo Clínico e Diretrizes Terapêuticas para Manejo da Infecção pelo HIV em Adultos. Ministério da Saúde, Secretaria de Vigilância em Saúde, Departamento de DST, Aids e Hepatites 2013. http://www.aids.gov.br/sites/default/files/anexos/publicacao/2013/55308/protocolo_13_3_ 2014_pdf_28003.pdf. Acesso em: 01/11/2015.

3) Boletim Epidemiológico - Aids e DST. Ano II - nº 1 - até semana epidemiológica $26^{\mathrm{a}}$ dezembro de 2013. Disponível em: http://www.aids.gov.br/sites/default/files/anexos/publicacao/2013/55559/_p_boletim_ 2013_internet_pdf_p_51315.pdf. Acesso em: 01/11/2015.

4) Garrafa, V. O novo conceito da bioética. In: Garrafa V, Kottow M, Saada A. Bases conceituais da bioética, enfoque latino-americano. São Paulo: Editora Gaia; 2006. P. 9-15.

5) Beauchamp, TL. The Four-principles approach. In: Principles of Health care ethics. EUA: John Wiley \& Sons. 1994: p. 03-12.

6) Garrafa, V. Ampliação e politização do conceito internacional de bioética. Revista Bioética. 2012; 20(1): 09-20.

7) Cortina, A. Ética aplicada y democracia radical. Madrid: Editorial Tecnos, 2012. 287p.

8) Fortes PAC, Zoboli ELCP. Bioética e Saúde pública: entre o individual e o coletivo. In: Fortes PAC, Zoboli ELCP (organizadores). Bioética e saúde pública. São Paulo: Editora do Centro Universitário São Camilo e Edições Loyola; 2004. p. 11-24.

9) Fortes, PAC. Reflexões sobre o princípio ético da justiça distributiva aplicado aos sistemas de saúde. In: Fortes PAC, Zoboli ELCP (organizadores). Bioética e saúde pública. São Paulo: Editora do Centro Universitário São Camilo e Edições Loyola; 2004. p. 35-47. 
10) Girard, G. HIV risk and sense of community: French gay male discourses on barebacking. Culture, Health and Sexuality. 2015; 17(10): 1-15.

11) Taylor, C. A Ética da Autenticidade: Edições 70, 2009. 234p.

12) Brasil. Resolução 466, de 12 de dezembro de 2012. Aprova as diretrizes e normas regulamentadoras de pesquisas envolvendo seres humanos. Disponível em: http://bvsms.saude.gov.br/bvs/saudelegis/cns/2013/res0466_12_12_2012.html. Acesso em: 20/11/2015.

13) Boletim Epidemiológico - Aids e DST. Ano II - n 1 - até semana epidemiológica $26^{\mathrm{a}}$ dezembro de 2013. Disponível em: http://www.aids.gov.br/sites/default/files/anexos/publicacao/2013/55559/_p_boletim_ 2013_internet_pdf_p_51315.pdf. Acesso em: 01/11/2015.

14) Boni, V; Quaresma, S J. Aprendendo a entrevistar: como fazer entrevistas em Ciências Sociais. Em Tese, v. 2, n. 1, p 68-80, jan./jul., 2005. Disponível em: <http://www.emtese.ufsc.br/3_art5.pdf>. Acesso em: 01/11/2014.

15) Camargo BV; Justo, AM. IRAMUTEQ: um software gratuito para análise de dados textuais. Temas em psicologia. 2013; 21 (2), 513-518.

16) Silva, RF. Compreender a "entrevista compreensiva". Disponível em: https://webcache.googleusercontent.com/search?q=cache:HT7vEednKvYJ:https://siga a.ufrn.br/sigaa/verProducao\%3FidProducao\%3D141926\%26key\%3Df6b11bddd35936 $\underline{8 \mathrm{a} 9 \mathrm{db} 356 \mathrm{aba} 03 \mathrm{~d} 27 \mathrm{db}+\& \mathrm{~cd}=1 \& \mathrm{hl}=\mathrm{pt}-\mathrm{BR} \& \mathrm{ct}=\mathrm{clnk} \& \mathrm{gl}=\mathrm{br}}$. Acessado em 28/02/2016.

17) Clouser KD, Gert B. A Critique of Principlism. Journal of Medicine and Philosophy. 1990; 15 (2): 219-236.

18) Garrafa V, Azambuja L. Epistemologia de la bioética - enfoque latino-americano. Revista Colombiana de Bioética. 2009; 4(1): 73-92.

19) Garrafa V. Inclusão Social no contexto político da bioética. Revista Brasileira de Bioética. 2005; 1(2): 122-132.

20) Garrafa V; Porto, D. Verbetes: Bioética de Intervención; Imperialismo moral; Bioética y política. In: Tealdi, JC (organizador). Diccionario Latino-Americano de Bioética. Bogotá: Unibiblos/UNESCO, 2008. 
21) Garrafa, V. Da bioética de princípios a uma bioética interventiva. 2005; 13(1): 125 134.

22) Fleury, S; Ouverney, AM. Política da Saúde: uma política social. In: Giovanella L, Escorel S, Lobato LVC, Noronha, JC, Carvalho, AI. Políticas e Sistema de Saúde no Brasil. Rio de Janeiro: Editora Fiocruz; 2014. P. 25-57.

23) Kerstenetzky, CL. O Estado de bem-estar social na idade da razão: a reinvenção do Estado social no mundo contemporâneo. Rio de Janeiro: Elsevier Editora Ltda; 2012.

24) Theodoro, M; Delgado, G. Política Social: universalização ou focalização - subsídios para o debate. Políticas Sociais - acompanhamento e análise. V. 7, 2003, IPEA.

25) Avritzer L. Sociedade civil e Estado no Brasil: da autonomia à interdependência política. Opinião Pública. 2012; 18 (2): 383-398.

26) Escorel, S; Moreira, MR. Participação Social. In: Giovanella L, Escorel S, Lobato LVC, Noronha, JC, Carvalho, AI. Políticas e Sistema de Saúde no Brasil. Rio de Janeiro: Editora Fiocruz; 2014. P. 853-883.

27) Ministério da Saúde. Departamento de Apoio à Gestão Participativa (DAGEP). Disponível em: http://portalsaude.saude.gov.br/index.php/oministerio/principal/secretarias/556-sgep-raiz/dagep/20656-conheca-o-departamento. Acessado em 10/02/2016

28) Marsiglia, R. M. G.; Silveira, C.; Junior, N. C. Políticas Sociais: desigualdade, universalidade e focalização na saúde no Brasil. Saúde e Sociedade v.14, n.2, p.69-76, maio-ago, 2005.

29) Kerstenetzky, C. L. Políticas Sociais: focalização ou universalização? Revista de Economia Política, vol. 26, nº 4 (104), pp. 564-574, outubro-dezembro/2006.

30) Plano Mais Brasil PPA 2012-2015: agendas transversais - monitoramento participativo: ano base 2012. Ministério do Planejamento, Orçamento e Gestão, Secretaria de Planejamento e Investimento Estratégico; Secretaria-Geral da Presidência da República, Secretaria Nacional de Articulação Social - Brasília: Ministério do Planejamento, Orçamento e Gestão/SPI, 2013.

31) Nascimento, S. Reflexões sobre a intersetorialidade entre as políticas públicas. Revista Serviço Social e Sociedade. 2010, , n. 101, p. 95-120, São Paulo. 
32) Avanços e Desafios da transversalidade nas políticas públicas federais voltadas para a minoria. In: Brasil em Desenvolvimento: Estado, planejamento e políticas públicas. Vol 3. Ipea, 2009.

33) Bourdieu P. O Poder Simbólico. Rio de Janeiro: Editora Bertrand Brasil; 1989. p. 163207.

34) Bourdieu P. Sobre o Estado: Cursos no Collège de France (1989-92). São Paulo: Editora Schwarcz S.A.; 2014, p. 54-80.

35) Brugué Q. Modernizar la administración desde la izquierda: burocracia, nueva gestión pública y administración deliberativa. Reforma y Democracia: No 29. 2004.

36) Sancho JC. La Invención de la Autonomía. Eidon. 2013; 39; 2012: 2-12.

37) Santos MS. Sobre a autonomia das novas identidades coletivas: alguns problemas teóricos. Revista Brasileira de Ciências Sociais. 1998, 13 (38): 1-16.

38) Montagner MA. Trajetórias e biografias: notas para uma análise bourdieusiana. Sociologias, Porto Alegre, ano 9, nº 17, jan./jun. 2007, p. 240-264

39) Hall, S. A identidade cultural na pós-modernidade. DP\&A Editora: 2002.

40) Alarcón S. La justicia comunitaria como sustento de la ética aymara. Integra Educativa, vol 2, n 3, p. 253-278.

41) Kashindi, JK. "Ubuntu" como modelo de justicia restaurativa. Um aporte africano al debate sobre la igualdad y la dignidad humana. Associación Latinoamericana de Estudios de Asis y África. XIII Congresso Internacional da ALADAA.

42) Garrrafa V. Inclusão Social no contexto político da bioética. Revista Brasileira de Bioética. 2005; 1 (2): 122-132.

43) Plano Diretor de Reforma do Aparelho do Estado. 1995. Disponível em: http://www.bresserpereira.org.br/documents/mare/planodiretor/planodiretor.pdf. Acessado em 13/02/2016. 
44) Cortina A. Ética Aplicada y Democracia Radical. Madri: Editorial Tecnos; 2012.

45) Cortina A. Bioethics and Public Reason: A Report on Ethics and Public Discourse in Spain. Cambridge Quartely of Healthcare Ethics. 2009; 18 (3): 241-250.

46) Cortina A.; M Emilio. Ética. Edições Loyola Jesuítas: São Paulo. 2013.

47) Scott JW. Desconstructing Equality-Versus-Difference: Or, the Uses of Posstructuralist Theory for Feminism. Feminist Studies. 1988; 14 (1): 33-50.

48) Segato RL. Antropologia e direitos humanos: alteridade e ética no movimento de expansão dos direitos universais. Mana. 12(1), 207-236. 2006.

49) Butler J. Relatar a si mesmo: crítica da violência ética. Belo Horizonte: Autêntica Editora. 2015.

50) Jonas H. O princípio responsabilidade: ensaio de uma ética para a civilização tecnológica. Rio de Janeiro: Contraponto: Ed. PUC-Rio. 2006.

51) Paranhos FRL. Crítica à teoria da moralidade comum como fundamentação do principialismo [Dissertação]. Brasília: Universidade de Brasília; 2015. 
APÊNDICES 


\section{Apêndice I - Roteiro de Entrevista}

Parte I. Identificação e caracterização socioeconômica

1. Nome

2. Idade

3. Escolaridade

4. Ocupação atual

5. Local de nascimento

Parte II. Justiça, equidade e universalidade das políticas sociais

1. O cargo da pessoa na gestão.

2. O que levou ela a escolher trabalhar com o tema de políticas sociais.

3. O que ela entende como política social.

4. O que ela entende como justiça, equidade e universalidade nas políticas sociais.

5. Há no Brasil um conceito claro que embase a ideia de justiça para as políticas sociais.

6. As políticas sociais são apenas para quem está em contexto de vulnerabilidade.

7. Já que as políticas sociais são para todos, como ele/ela vê a possibilidade de autonomia de uma pessoa não querer se tratar, por exemplo, no caso de saber que é HIV positivo.

8. Fala livre da(o) entrevistada(o) sobre o tema/Formulação de novas perguntas, a depender da entrevista. 


\section{Apêndice II - Termo de Consentimento Livre e Esclarecido (TCLE)}

Você está sendo convidado(a) a participar da pesquisa "Entre as políticas sociais e a autonomia a partir dos conceitos bioéticos: o exemplo da política de HIV/aids", sob responsabilidade da pesquisadora Rafaela Mendes Medeiros. Sou aluna de mestrado em Bioética pela UnB, sob orientação do prof. Miguel Montagner. O objetivo dessa pesquisa é entender melhor, à luz do conceito de autonomia e justiça da bioética, perpassado pela ideia de pessoas que hoje são consideradas grupos de vulnerabilidade em relação ao HIV/Aids no Brasil, como os conceitos de justiça e de autonomia são vistos por formuladores e gestores de políticas sociais de saúde.

$\mathrm{O}$ (a) senhor(a) receberá todos os esclarecimentos necessários antes e no decorrer da pesquisa e lhe asseguramos que seu nome não aparecerá, sendo mantido o mais rigoroso sigilo pela omissão total de quaisquer informações que permitam identificá-lo(a).

A sua participação se dará por meio de entrevista individual e você pode recusar-se a participar, retirar seu consentimento ou interromper sua participação a qualquer momento. Também poderá se recusar a responder qualquer questão que lhe traga constrangimento, podendo desistir de participar da pesquisa em qualquer momento sem nenhum prejuízo para o mesmo.. As entrevistas serão realizados em suas salas de trabalho ou em lugar que acharem mais agradável, de acordo com o melhor horário considerado por você. Sua participação é voluntária, isto é, não há pagamento por sua colaboração.

A pesquisa a se realizar há benefício ao buscar entender melhor a política de HIV/Aids no país e a forma como as pessoas veem o tratamento em relação às ações da política nacional. Garanto a você o acesso aos benefícios provenientes de sua inserção na pesquisa ao ter acesso aos resultados da investigação, além de garantir que sua colaboração não será utilizada com o intuito de te prejudicar.

Todas as despesas que você tiver relacionadas diretamente ao projeto de pesquisa (tais como, passagem para o local da pesquisa, alimentação no local da pesquisa ou exames para realização da pesquisa) serão cobertas pelo pesquisador responsável.

Caso haja algum dano direto ou indireto decorrente de sua participação na pesquisa, você poderá ser indenizado, obedecendo-se as disposições legais vigentes no Brasil.

Os resultados da pesquisa serão divulgados na Universidade de Brasília, podendo ser publicados posteriormente. Os dados e materiais serão utilizados somente para esta pesquisa e 
ficarão sob a guarda da pesquisadora por um período de cinco anos, após isso serão destruídos.

O convite está sendo feito para que você participe de uma entrevista. A entrevista consiste em primeiramente uma parte sobre identificação e caracterização socioeconômica e outra sobre justiça, equidade e universalidade das políticas sociais: seu cargo na gestão; o que levou ela a escolher trabalhar com o tema de políticas sociais; o que você entende como política social; o que você entende como justiça, equidade e universalidade nas políticas sociais; se há no Brasil um conceito claro que embase a ideia de justiça para as políticas sociais; se as políticas sociais são apenas para quem está em contexto de vulnerabilidade; como você vê a possibilidade de autonomia de uma pessoa não querer se tratar, por exemplo, no caso de saber que é HIV positivo.

Assim, consulto-a(o) sobre seu interesse e disponibilidade de colaborar. Você receberá os esclarecimentos necessários antes, durante e após a finalização da pesquisa. As entrevistas serão gravadas, mas the asseguro que seu nome não será divulgado, sendo mantido sigilo sobre informações que permitam identificá-la(o). Os dados provenientes de sua participação, tais como anotações ou fitas de gravação, ficarão sob minha guarda. Os resultados serão divulgados em minha dissertação, artigos acadêmicos e eventos, lembrando sempre que sua identidade será preservada. Portanto, garanto a manutenção do sigilo e da privacidade durante todas as fases da pesquisa.

Ressalto que realizo a pesquisa na condição de estudante, sem qualquer vínculo com poderes públicos, hospitais, maternidades, consultórios ou clínicas médicas.

Este projeto foi Aprovado pelo Comitê de Ética em Pesquisa da Faculdade de Ciências da Saúde (CEP/FS) da Universidade de Brasília. O CEP é composto por profissionais de diferentes áreas cuja função é defender os interesses dos participantes da pesquisa em sua integridade e dignidade e contribuir no desenvolvimento da pesquisa dentro de padrões éticos. As dúvidas com relação à assinatura do TCLE ou os direitos do participante da pesquisa podem ser esclarecidos pelo telefone (61) 3107-1947 ou do e-mail cepfs@unb.br ou cepfsunb@gmail.com, horário de atendimento de 10:00hs às 12:00hs e de 13:30hs às 15:30hs, de segunda a sexta-feira. O CEP/FS se localiza na Faculdade de Ciências da Saúde, Campus Universitário Darcy Ribeiro, Universidade de Brasília, Asa Norte.

Meu nome é Rafaela Mendes Medeiros e você pode me contatar por meio do telefone (61) 8156-8876 e e-mail invisiveiscidades@gmail.com. Você pode me telefonar qualquer horário durante a semana entre $08 \mathrm{~h}$ e $18 \mathrm{~h}$. Caso necessite ligar a cobrar, pode fazê-lo nos 
mesmos horários indicados. Você também pode contatar o meu orientador, Miguel Montagner, pelo e-mail montagner@unb.br ou pelo telefone (61) 8142-4277.

Este documento foi elaborado em duas vias, uma ficará com o pesquisador responsável e a outra com o Senhor(a).

Nome / assinatura

Pesquisador Responsável

Nome e assinatura

Brasília, de de 